\title{
Optimal Capital Taxation Rates and Tax Competition in Open Economy
}

Séverine Menguy*

Université Paris Descartes, France

\begin{abstract}
The model presented in this paper provides accurate theoretical results regarding optimal taxation rates and fiscal externalities in an open economy. We show that for both capitalimporting and capital-exporting countries, capital taxation rates should increase with country size approximated by its capital stock. In parallel, for the smallest countries, the fiscal weight could be very high and strongly relies on the labor production factor. It is also demonstrated that the optimal capital taxation rate increases with the relative preference of the representative consumer for private consumption, in contrast to public consumption, as well as with the capital share in the production function. Furthermore, the presented model shows that the slope of the tax reaction function is positive as soon as the preference of the representative consumer for private goods consumption is sufficiently high.
\end{abstract}

JEL Classifications: H21, H25, H87

Keywords: Tax competition, Capital importing country, Capital exporting country, Optimal capital taxation rate, Fiscal externalities

\footnotetext{
* Corresponding Author: Séverine MENGUY; Professor, Université Paris Descartes, Sorbonne Paris Cité, 12 rue de l'école de médecine, 75270 PARIS CEDEX 06, France. Tel: 00331466894 84. Email: severine.menguy@orange.fr.
} 


\section{Introduction}

Economic integration and the higher level of openness among current economies have fundamental consequences for national budgetary independence. Indeed, in an open economy framework, fiscal policy is necessarily constrained by partner countries' taxation rates. With the extent of international integration rising, national governments lose some of their monopoly power over fiscal policy in a situation of strategic interaction with foreign counterparts. Furthermore, living within a monetary union has likely also increased the degree of factor mobility. Specifically, in the context of the European Economic and Monetary Union (EMU), there is now a higher degree of factor mobility across member states, especially capital movement. The economics literature has repeatedly provided evidence that capital movements have become more responsive to capital taxation levels in response, implying a higher degree of tax competition among member states. ${ }^{1}$ Because this situation accentuates tax competition issues, the need to have a shared view on these issues is exacerbated. Tax competition is defined as non-cooperative tax-setting by independent governments whereby each government's policy choices influence the allocation of a mobile tax base among regions or countries, that is, fiscal externalities. For example, regarding the taxation of capital, which is a highly mobile factor, a country could consider itself to benefit by conducting a beggar the neighbor policy of reducing its tax rates in order to attract a larger tax base. This results in a situation where tax rates become fixed un-cooperatively at an inefficiently low level. Accordingly, from the very start of the EMU, such a situation of tax competition and of race to the bottom was feared and was studied.

What fiscal base is the most feared in this situation of tax competition? Tax harmonization regarding consumption of goods and services (indirect taxes) is fundamental to the common market and functioning of a common customs union like the European Union (EU). Therefore, coordination is more developed in the EU regarding commodities. Nevertheless, even in this field, large discrepancies remain, and harmonization remains very limited, even today. Indeed, regarding consumption, the destination principle usually

\footnotetext{
${ }^{1}$ See for example Zodrow (2010) for a complete survey on various measures of the increased international capital mobility, and for results on tax competition among Organisation for Economic Co-operation and Development countries since the second half of the twentieth century. See Wilson (1999) for a very complete review of the literature on theories of tax competition.
} 
prevails: exports are not taxed by the exporting country but by the importing country. Thus, an origin-based taxation system is applied only for crossborder shopping. However, because the share of cross-border shopping is negligible in terms of total trade, tax competition in the field of consumption is a phenomenon that remains limited and constrained. In contrast, personal and corporate taxation (direct taxes) mainly affect the mobility of labor and capital, a mobility which is less developed. As a result, European harmonization is also less developed in these fields. More precisely, labor mobility remains quite low in Europe today, except perhaps for the more highly skilled workers. However, tax competition highly concerns corporate taxes, which is the subject of the current paper.

Regarding the capital production factor, the consequences of higher economic integration should be further explored. The efficiency hypothesis predicts that competing for a mobile tax base will erode the national tax rate on a mobile factor. Indeed, a source-based tax on a mobile factor (capital) appears counter-productive and inefficient because it could greatly shrink the fiscal base (the capital stock). This potential capital outflow implies that the fiscal burden mainly rests on local residents in the form of higher taxes on labor or land property, or higher prices for non-tradable goods. In contrast, the compensation hypothesis argues that governments could increase their social and welfare expenditure in order to insure the citizens against the increased economic risk generated by globalization. Other studies (Baldwin and Krugman 2004, Sorensen 2006, and the analysis in Section II.A) have also underlined that despite tax competition, capital taxation should persist in the future and remain at non-negligible levels, particularly in order to capture unusual profits and location rents.

In light of these myriad theories, the current paper aims at understanding why optimal capital taxation rates should remain positive even in an open economy framework where fiscal externalities exist between the choices of a capital-exporting and capital-importing country. Therefore, beyond the traditional parameter of country size usually used in the economics literature, our contribution is also distinguishing analytically between the cases of capital importing or exporting countries. Even if the risk of reducing capital taxation rates to inefficiently low levels exists for the smallest countries, we find that optimal capital taxation rates are unambiguously positive for the biggest countries. 
We also show that there are significant and non-negligible interdependencies between taxation rate levels of capital-importing and capital-exporting countries in an open economy framework. The slopes of the tax reaction functions have extensively been studied in the economic literature. These slopes are usually positive, which means that if the capital taxation rate in the foreign country decreases, the taxation rate in the national country should also decrease in order to avoid leakage of the fiscal base. However, our paper's contribution is to show that these externalities mainly depend on the relative preference of the representative household for the consumption of private versus public goods and services, according to an accurate analytical condition.

The rest of the paper is organized as follows. The second section discusses the economic literature's findings regarding the theoretical mechanisms of tax competition and its empirical evolution, particularly in the EMU. The third section describes the theoretical model used to study optimal taxation rates in a model with two countries, where governments aim to maximize the utility of a representative consumer. The fourth section analyzes the optimal labor and capital taxation rates in open economy in the respective cases of a capital-importing and a capital-exporting country. The fifth section examines the fiscal externalities between both countries and the sign of the slopes of the fiscal reaction functions. Finally, the sixth section concludes the paper.

\section{The Economics Literature}

\section{A. Theoretical mechanisms of tax competition}

Oates (2001) underlines that the desirability of fiscal competition depends in important ways on the underlying view of how the public sector works. If public decision-makers are seen as trying to maximize society's wellbeing, fiscal competition may imply distortions that excessively constrain the public sector's size. However, if the state is seen as a Leviathan whose size is excessively large (Brennan and Buchanan), fiscal competition may be welfare-enhancing by reducing and/or improving the efficiency of the public sector, thereby allowing it to reach Pareto-optimal levels of public activities and efficiently constraining the extent of public expenditure and public 
indebtedness.

In the first tradition that underlines the necessity to provide a sufficient level of public services, Sinn (1997) stresses that the government can perform some functions better than the market. He shows that tax competition could be ruinous for governments because of congestion-prone public goods; in these conditions, charging for use of public infrastructure does not generate enough revenue to cover the cost of providing this infrastructure. The harmful consequence is not, however, an under-provision of public goods, but a distribution of the fiscal burden to rely more on immobile factors. In addition, regarding the government's redistribution function, reducing the state's size could introduce adverse selection, in conformity with private market mechanisms, into this insurance function. Finally, tax competition could result in efficiently low quality standards for consumption goods.

In the same way, Oates (2001) explores the emerging structure of the public sector in the EU in the presence of growing fiscal competition. Starting from a perspective of traditional fiscal federalism, he assumes that this structure may be ill-suited to performing two traditional tasks of public finance: supporting for the poor and achieving macroeconomic stabilization. Furthermore, Wilson (1986) mentions the possibility that tax competition implies inefficiently low taxation rates and, consequently, provision of public services. Indeed, the incentive to attract capital (mobile tax base) through a low taxation rate fails to take into account the beneficial externality of fiscal resources to produce public services. As Wildasin (1988) explains, the social cost of local public goods is less than their private cost. Thus, under-provision of local public goods arises because communities fail to take into account the beneficial externalities those goods confer on other communities.

Keen and Marchand (1997) also underline that beyond increasing the share of the tax structure that relies on immobile factors, tax competition may also lead to an increase in public expenditures that benefit mobile capital at the expense of those benefiting immobile consumers. They assume that welfare would be improved by increasing the public provision of local public goods that benefit immobile consumers. Accordingly, some of the previous literature has shown that competition among regional governments may result in inefficiently low levels of capital taxation. This could occur because governments do not consider the external benefits of capital flight to other regions that would result if they choose higher taxation rates. However, the 
fiscal distortion is smaller when the supply of capital is more elastic or if governments are not perfectly competitive. Indeed, Parry (2003) shows that the welfare cost of tax competition can even disappear if governments behave in part as a revenue-maximizing Leviathan.

Other authors also underline the dangers of over-provision of public goods and services without some degree of tax competition. Wildasin and Wilson (2004) review the potential advantages and disadvantages of tax competition specifying some situations where tax competition could be welfare-enhancing: (1) by eliminating wasteful subsidies to foreign exporting firms, or (2) by reducing inefficient public services that are very weakly productive, i.e., weak marginal benefit. Competition could then contribute to driving taxes toward the marginal cost for the collectivity of public services production, which could be welfare-enhancing even if it could also damage a country's redistributive and social insurance policy (Wildasin 2002). In the same way, Dhillon et al. (2007) use a classic model of tax competition to show that in a Nash equilibrium, when public goods have a positive impact on productivity, tax competition does not necessarily result in a race to the bottom. Alternatively, tax competition can be efficient, or there can be a race to the top when there is over-provision of public goods and tax rates are too high. Such a case arises when the marginal benefit of public good provision is above its marginal cost.

Furthermore, Wilson (1991) studies tax competition between two regions that tax inter-regionally-mobile capital in order to finance local public goods. In a Nash equilibrium, he finds that residents of a relatively small population size region are better off than residents of the large region. Indeed, the small region can chose a lower taxation rate because its capital supply is more elastic capital with respect to tax rate changes. Therefore, tax competition would be more beneficial for the smallest countries. Indeed, Wilson (1991) analyzes asymmetric tax competition between a large region and a small region, each possessing the same endowments of capital and labor. Because the large region has greater demand in the capital market, an increase in its tax rate depresses the after-tax return on capital by a relatively large amount. Thus, the large region, which will compete less vigorously for capital through tax reductions and therefore end up with a higher tax rate. Smallness therefore confers the advantage of allowing the small region to have a lower cost of capital in equilibrium. Therefore, firms there employ more capital per unit of 
labor and offer higher wage rates than in the large region.

Despite these ambiguous theoretical results regarding the advantages and disadvantages of tax competition, the latter should anyway remain quite limited, mainly because of location-specific rents. Indeed, using a panel data set on Western European countries, Baldwin and Krugman (2004) show that agglomeration forces can reverse standard international-taxcompetition results. More precisely, closer integration may result first in a race to the top and then a race to the bottom, a result consistent with recent empirical findings that the tax gap between rich and poor nations follows a bell-shaped path. Agglomeration forces create quasi-rents that can be taxed without inducing delocalization. Indeed, advanced core nations benefit from advantages like an established base of infrastructure and accumulated experience, which imply favorable external economies that allow them to impose higher taxation rates than less advanced nations, even on mobile capital.

Therefore, location decisions of multinational firms are mainly influenced by the local market and institutional conditions inside the host country. Fundamental factors include proximity to markets, costs of various primary and intermediate inputs, skill levels available in local labor markets, the local competitive, legal, and regulatory environment, and the degree of political stability, including the credibility of government commitments to enforce property rights. For example, Garretson and Peeters (2006) study 19 Organisation for Economic Co-operation and Development (OECD) countries between 1981 and 2001. Their main conclusion is that increased international capital mobility, measured by volume of Foreign Direct Investment (FDI) implies a lower corporate tax rate. Nevertheless, they also underline that core countries can afford higher tax rates than peripheral countries because agglomeration of economic activities, measured by population per $\mathrm{km}^{2}$, matters.

Kind et al. (2000) use a new economic geography model to analyze tax competition between two countries trying to attract internationally mobile capital. Each government may levy a source tax on capital and a lump-sum tax on fixed labor. Therefore, the analysis finds that if industry is concentrated in one countries (agglomeration force), the host country will gain from setting its source tax on capital higher than that of the other country. In particular, the host country may increase its welfare per capita by setting a positive 
source tax on capital, thus capturing the positive externality that arises in the agglomeration. Capital becomes effectively immobile due to pecuniary externalities arising in the agglomeration. Sorensen (2006) identifies location specific rents as rents arising due to factors such as existence of natural resources, attractive infrastructure, availability of a pool of qualified labor, and, more generally, the existence of agglomeration forces. These forces explain why corporate taxes will not disappear even in a framework of capital mobility. In fact, whereas normal returns on capital are difficult to tax and could tend to vanish (these are empirically very weak today), these specific rents on capital should continue to be taxed in the future.

Accordingly, supporters of corporate income taxes see such taxes as a means of capturing some of the economic rents earned by foreign multinationals and domestic corporations. Furthermore, in the short run, capital is not instantaneously mobile because costs arise when moving the capital stock from one country to another. Slemrod (2004) underlines that corporation taxes' important role as a backstop to individual income taxes; the statutory corporate tax rate is higher in countries in which the top individual tax rate is also high. Indeed, a high corporate income tax avoids behaviors such as the reclassification of high labor income as business income in order to allow a weaker effective tax rate. This is another reason why nonnegligible corporate income taxes should persist empirically.

\section{B. Empirical evolution of corporate taxation rates in the EU}

In addition to the aforementioned theoretical considerations on potential consequences and likely evolution of capital tax competition between more integrated economies, studies have analyzed the empirical evolution of corporate taxation rates in an integrated zone like the EU as a clear signal of intensifying tax competition.

A first group of studies examine the relationship between capital tax burdens and degree of capital mobility: higher capital mobility is supposed to generate a race to the bottom in taxes on mobile capital taxed at source. Consequently, numerous studies find that tax competition leads to inefficiently low tax rates on mobile tax bases (corporate taxes), with the tax burden shifted to less mobile factors (labor or consumption taxes). For example, Devereux and Sorensen (2006) show that statutory corporate tax rates have 
fallen substantially since the early 1980s, although the pace of reductions has varied over time, it appears to be continuing, probably because of competitive pressure. In the same way, Devereux et al. (2002) note that average statutory corporate income tax rates in the EU and the US fell dramatically from $48 \%$ in 1982 to $35 \%$ in 2001 . At the same time, however, these rate reductions have often been accompanied by base-broadening efforts so that overall corporate tax revenues in proportion of Gross Domestic Product (GDP), as well as average and especially marginal effective tax rates have declined by considerably less.

In fact, in OECD countries, corporate tax revenues as a fraction of GDP have been roughly constant over the past 40 years. They have even increased around 2010 (Devereux 2007). Bond et al. (2000) also show that between 1980 and 2000, corporate tax revenues have not decreased in proportion of GDP. Indeed, several countries have financed rate reductions by making depreciation allowances less generous and/or by eliminating other deductions (broader basis). More precisely, Devereux et al. (2002) establish a number of stylized facts about the development of corporate income taxes in EU and G7 countries between 1980 and 2002. They show that tax-cutting and base-broadening reforms have on average, allowed effective tax rates on marginal investment to remain fairly stable, whereas those on more profitable investments (location of attractive and more mobile multinationals) have fallen. In the same way, Hines (2007) shows that despite growing international capital mobility, corporate tax collections are remarkably persistent relative to GDP, government revenues, or other indicators of underlying economic activity or government need. According to the author, it seems that less mobile national capital has continued to be highly taxed while the tax burden has decreased in order to attract more mobile international investors.

In fact, although there was a period of strong corporate tax rate reductions, particularly around the time of eastern enlargement of the EU, this process has slowed down significantly after 2005. Indeed, given that the completion of the single market generally increased Europe's attractiveness for international investment, it seems plausible that EU member states can maintain their nowmoderate level of corporate taxation in the future, even in a framework of international tax competition.

However, regarding the composition of the tax burden, Sorensen (2001) 
mentions that labor taxes, such as personal income taxes related to labor, payroll, social security taxes, have risen between the 1980s and 2000s, whereas capital taxes, such as taxes on corporate income, taxes on personal income related to property, wealth, etc., remained much more stable. Therefore, although tax competition does not lead to under-provision of public goods, it implies an unfair distribution of the tax burden to the detriment of immobile labor. Sorensen (2003) also shows that between 1985 and 1995, when international capital flows increased considerably, the higher overall tax burden experienced in most countries was concentrated on labor.

In the same way, Bretscher and Hettich (2002) show that globalization has a positive effective on the ratio of the effective labor tax rate to the corporate tax rate, verifying the shift in OECD countries from corporate taxation to taxation of less mobile tax bases. Studying a panel of 14 OECD countries for the period of 1967 1996, they find that globalization, an indicator of global economic integration, has indeed had a negative and significant impact on statutory corporate taxes. They also find that globalization tends to raise labor taxes, which are less elastic (efficiency hypothesis) as well as social expenditures (compensation hypothesis).

Tax competition has been feared since the creation of the EMU. Therefore, tax harmonization measures were proposed in order to avoid a potentially harmful slide toward inefficiently low capital taxation rates. For example, Sorensen (2000) investigates the scope for pan-European coordination of capital income taxes because higher taxation rates may cause capital leakage to the rest of the world. The analysis highlights the differences between tax coordination at the global level and regional coordination among a subset of countries at the European level in particular. He finds that although tax competition will generate an inefficiently low level of capital taxes relative to taxes on labor, which will reduce redistributive public transfers. However, international tax coordination could be justified according to egalitarian political motives, but it actual political implementation will be difficult because it would decrease the global capital stock. Haufler (1999) also assumes that a certain level of aggregate efficiency gains can be expected from a coordinated the EU tax policy in order to collect a global European rent to locate in the European market. However, additional tax collections will be largely limited to the group of small savers, because highly mobile largescale investors and big multinationals are likely to avoid EU taxes through 
profit-shifting strategies and investment in third countries.

Accordingly, Eggert and Haufler (2006) study European Commission's 2001 proposal to introduce a common consolidated tax base under which the total income of a group of interconnected multinational firms would be determined and the tax base allocated among the involved jurisdictions according to a pre-determined mechanism (formula apportionment). However, this possibility was found to have ambiguous economic incentive effects because it creates distortions that incentivize investment in low-tax countries. Indeed, the proposal does not necessarily harmonize statutory tax rates applied to the commonly defined share of the tax base by each national country. Therefore, Gorter and de Mooij (2001) assume that full harmonization of tax rates and tax bases in Europe would be more beneficial. Such a move would improve the system's simplicity and neutrality and avoid fiscal spillovers among countries. Nevertheless, the authors argue that the welfare gain would be quite small, between 0 and $2 \%$ of GDP, and it would mainly benefit the largest countries and poorest parts of the population.

In the same way, Sorensen (2001) argues that a fully harmonized statutory corporate tax bases and tax rates combined with formula-based apportionment might be a legitimate long-term goal for EU tax policy. However, Sorensen (2003) recognizes that if such a policy is indeed a legitimate long-term goal, tax harmonization in Europe would create winners and losers. For example, Denmark would suffer much more than Germany where corporate taxes are much higher from a decrease of the corporate taxation rate. Therefore, persuading smaller countries to adopt a higher harmonized European rate would be difficult without some compensation for the potential cost in terms of investment forgone. Indeed, direct taxation remains one of the areas not covered by majority voting in the EU, meaning that any directives or regulations can only be passed with unanimity.

In this context, Haufler and Lulfesmann (2015) also show that in a monetary union, small members are the winners of tax competition and therefore have no political and institutional motivation to agree on tax harmonization. Those authors find that the best solution would be a dual capital taxation system wherein asymmetric union member states agree on some uniform, and maximum federal tax rate in the first stage, and then noncooperatively set local tax rates in the second stage.

Nevertheless, in the framework of this broad economic literature, the 
current paper aims to provide an accurate analytical demonstration that a positive capital taxation rate is justified, even in a static framework as well as in a framework of tax competition and positive fiscal externalities among countries in open economy for capital-exporting as well as capital-importing countries. Therefore, implementing a positive capital taxation rate could mitigate the necessity of complex tax harmonization measures mentioned in the economic literature.

\section{The Model}

This section describes the detailed analytical model aimed at shedding a new light on tax competition and fiscal interdependencies among economically integrated countries. We begin by explaining why the origin principle is the most suitable analytical framework for studying corporate taxation.

\section{A. Source- rather than residence-based corporate taxation}

According to the residence principle, residents are taxed on their worldwide income equally, regardless of whether the income is domestic or foreign in origin. Therefore, it functions as a tax on saving. Meanwhile, personal taxes on capital and wealth, i.e., dividends, interest, and royalties (portfolio income) are usually taxed on a residence basis. A resident of any country must earn the same net return on savings, no matter which country is chosen as the location of those savings. Thus, the marginal product (return) of capital must be the same in all countries even in a context of free movement of capital. However, if the tax rates differ, then the net returns accruing to savers in different countries vary and the international allocation of global savings is distorted. Furthermore, although personal taxes on income and wealth are formally based on the residence principle, it is often very difficult in practice for domestic tax authorities to monitor the return to a taxpayer's personal wealth invested abroad. For this reason, even personal taxes on capital may end up falling mainly on capital invested at home, as would be the case if the source principle were applied.

In the area of corporate income taxation, many countries explicitly exempt 
foreign-source corporate income from domestic taxes if the foreign income originates from a tax-treaty partner country. For example, a large number of the EU member countries explicitly adhere to the source principle. Profits are only taxed in the country where the subsidiary is located. Similarly, some important capital-exporting countries like the US, the UK, and Japan only tax worldwide profits of their multinationals to the extent that this income is repatriated to the parent company, in the form of dividends (Sorensen 2006), taxation applies only in so far as the national tax liability exceeds the source tax that has already been paid to the foreign country. This means that a country may subject foreign-source profits to domestic corporate income tax but grant a credit for source-country taxes against the domestic tax bill (Italy, Greece). As long as profits are retained and reinvested abroad, only the host country's taxation rate matters for the cost of capital. Taxation at the margin is then effectively source-based. Besides, when the effective foreign tax rate exceeds the national tax rate, even at the time of repatriation, investors end up paying a higher foreign tax rate on their foreign income. As a first approximation, it is therefore fair to say that the source principle prevails in the taxation of capital.

Furthermore, although small domestic household investors tend to have no or only small direct holdings of foreign assets in their portfolios, the domestic bias in sparing location, Sorensen (2006) underlines that a large part of household savings is channeled through institutional investors such as mutual funds, pension funds, and life insurance companies, who may hold significant amounts of foreign assets. However, in practice, it is quite difficult to tax capital income on a residence basis independent of where it is owned. Administrative and tax-compliance problems involved in taxing foreign-source income are much more severe than those associated with taxing domestic income. Information must be exchanged among banks and fiscal authorities, in terms of withholding arrangements and loosening bank secrecy laws. As result, researchers have usually investigated models where residence-based taxation is either limited or unavailable, and they consider that current taxation of corporate profits follows de facto closely the source principle.

According to the source principle, a country's residents are not taxed on incomes from foreign sources, and foreigners are taxed equally as residents on income from domestic sources. Therefore, it acts as a tax on investment, 
like the corporate tax, for example. Because residents in country $i$ must earn the same net return whether they channel savings to country $i$ or country $j$, it follows that residents of all countries earn the same net return. Thus, intertemporal marginal rates of substitution are equalized across countries, implying that the international allocation of global savings is efficient. However, if the tax rate is not the same in all countries, then the marginal product of capital varies and the international allocation of the world stock of capital is not efficient (production inefficiency).

Although these are two extreme principles of international taxation, in reality, countries adopt a mixture of these principles. For example, Razin and Sadka (1991) show that when a government can effectively tax foreignsource income, it is not efficient to impose restrictions on capital exports. The optimal tax rates on foreign source and domestic-source income are then the same, and this equality ensures an efficient allocation of the country's savings between investment at home and abroad. However, when the government cannot tax foreign-source income, it is optimal to impose a restriction on capital exports so as to induce over-investment in domestic capital. This in turn decreases the necessary before-tax return of national investment.

In the current paper, we concentrate on the corporate income tax based on the origin principle, which has significant consequences on investment in a given country. In contrast, variations in personal income taxes, mainly based on the residence principle, have less pronounced consequences (Sorensen 2006). The model is static, describing a stationary long-run equilibrium.

We consider a monetary union made of two member countries: $i$ and $j$. The economies are perfectly competitive, goods market are perfectly integrated, and financial capital is perfectly mobile. We assume that both countries belong to a larger world economy that defines the average world return of an investment in particular, and that both countries are small and have no influence on average world economic variables. In each member country, the government maximizes the utility of a representative consumer/household; each jurisdiction also contains a representative firm. The two governments play a Nash game in tax rates, and the economy is in equilibrium when each government choses its optimal tax rate given the tax rate chosen by the other government. Labor is immobile between countries, but there is free international movement of capital. Each country may levy taxes on wages including social security taxes and indirect taxes on consumption and capital 
income. Income distribution issues are ignored by assuming (1) that each region's residents are identical or (2) that their aggregate welfare can be depicted by the preferences of a representative consumer.

\section{B. The representative consumer}

The representative consumer in the country $i$ maximizes a utility function depending on consumption of private and public goods, as well as on labor supply. For simplicity, we suppose that public expenditure by country $i$ 's government benefits only residents of its own country. So, the utility function of the representative consumer in the country $i$ is as follows:

$$
U_{i}=\alpha_{c} \log \left(C_{i}\right)+\alpha_{g} \log \left(G_{i}\right)-\alpha_{l} \frac{1}{(1+\varphi)} L_{i}^{1+\varphi}
$$

with $\left(C_{i}\right)$ : real consumption of private goods, $\left(G_{i}\right)$ : real public expenditure (consumption of public goods), $\left(L_{i}\right)$ : labor supply, and $\left(\alpha_{\mathrm{c}}\right),\left(\alpha_{\mathrm{g}}\right)$ and $\left(\alpha_{1}\right)$ are the respective weights given by the representative consumer to consumption of private goods, public goods and labor supply.

Maximizing this utility function is subject to a budgetary constraint. Indeed, the representative consumer may consume any non-human wealth immediately or invest it in the capital market and consume it at the end of the period. Thus, the representative consumer of country $i$ consumes private goods and invests in capital. The share of revenues not spent on consumption of private goods by the representative consumer, e.g., savings, is the share that can be invested in the capital market. Regarding resources, the representative consumer receives labor (wage) and capital (interest rate) revenues. Indeed, we suppose that capital is rented by households to firms, for which they receive a rental rate. Accordingly, the budgetary constraint of the representative consumer in the country $i$ is:

$$
\begin{gathered}
C_{i}+K_{i, .}^{s}=\left(1-t_{i}^{l}\right) w_{i} L_{i}+\left(1-t_{i}^{k}\right) r_{i} K_{i, i}^{S}+\left(1-t_{j}^{k}\right) r_{j} K_{i, j}^{s} \\
C_{i}=\left(1-t_{i}^{l}\right) w_{i} L_{i}-\left(1-r_{i}+r_{i} t_{i}^{k}\right) K_{i, i}^{s}-\left(1-r_{j}+r_{j} t_{j}^{k}\right) K_{i, j}^{s}
\end{gathered}
$$

where $\left(t_{i}^{l}\right)$ : labor taxation rate in the country $i,\left(t_{i}^{k}\right)$ : capital taxation rate in 
the country $i,\left(K_{i, j}^{S}\right)$ : capital from households in the country $i$ invested in the country $j,\left(w_{i}\right)$ : real wage rate (labor cost), $\left(r_{i}\right)$ : real interest rate (capital cost). $\left(K_{i, i}^{s}+K_{i, j}^{s}=K_{i,}^{s}\right)$ : capital supply from households in the country $i$, $\left(K_{j, j}^{s}+K_{j, i}^{s}=K_{j, .}^{s}\right)$ : capital supply from households in the country $j$.

The origin principle implies that agents are taxed at the same rate $\left(t_{i}^{k}\right)$ for the capital invested in the country $i$ regardless of nationality.

The two countries can differ in size, but labor is immobile between them. However, capital is assumed to be internationally mobile. Therefore, regarding the capital supply, we introduce very simple functions. Residents in the country $i$ invest respectively in the countries $i$ and $j$ according to the differential of profitability between the two countries:

$$
K_{i, i}^{S}=h K_{i, .}^{S}+\frac{(1-h)\left(r_{i}-t_{i}^{k}\right)}{\left(r_{i}+r_{j}-t_{i}^{k}-t_{j}^{k}\right)} K_{i, .}^{S} \quad K_{i, j}^{S}=\frac{(1-h)\left(r_{j}-t_{j}^{k}\right)}{\left(r_{i}+r_{j}-t_{i}^{k}-t_{j}^{k}\right)} K_{i, .}^{S}
$$

where $(h)$ : capital share allocated to the home country, and $(1-h)$ : capital share allocated according to respective returns.

The representative consumer in the country $i$ invests more in country $j$ because the taxation rate is weaker in country $j$, as $\left(t_{j}^{k}<t_{i}^{k}\right)$ and the aftertax net real interest rate is then higher in the foreign country. However, we also take into account the empirical home-bias behavior of economic agents. Capital is only un-perfectly mobile between countries because there is a tendency to invest in the home country $(h)$, and imperfect substitutability between home and foreign assets.

Households are free to invest their capital wherever they want. Accordingly, assuming rational behavior, capital moves across borders to seek the highest net-of-tax return. Allocation is then defined according to post-tax rates of return, which are equated across countries. Therefore, when the representative consumer choses an investment, the profitability of private firms decreased by the taxation rate that will have to be paid on this profitability must be the same across all firms in all member countries as well as equal to the world capital rate of return $(\rho)$ defined on the world financial market. This leads to the following capital arbitrage condition: 


$$
r_{i}\left(1-t_{i}^{k}\right)=r_{j}\left(1-t_{j}^{k}\right)=\rho
$$

Because $\frac{\partial r_{i}}{\partial t_{i}^{k}}=\frac{\rho}{\left(1-t_{i}^{k}\right)^{2}}>0$, the required before-tax real interest rate increases with the capital taxation rate to obtain the same post-tax real return.

For the representative household in country $i$, maximization of utility for a given taxation rate $t$ implies:

$$
\left(\frac{\partial U_{i}}{\partial t}\right)=\frac{\alpha_{c}}{C_{i}}\left(\frac{\partial C_{i}}{\partial t}\right)+\frac{\alpha_{g}}{G_{i}}\left(\frac{\partial G_{i}}{\partial t}\right)-\alpha_{l} L_{i}^{\varphi}\left(\frac{\partial L_{i}}{\partial t}\right)=0
$$

Therefore, for a given level of labor supply, we obtain:

$$
-\alpha_{c} G_{i}\left(\frac{\partial C_{i}}{\partial t}\right)=\alpha_{g} C_{i}\left(\frac{\partial G_{i}}{\partial t}\right)
$$

This implies that the loss in terms of weaker purchasing power and consumption of a higher taxation rate must equal the gains in terms of a higher level of public services provided. The marginal rate of transformation between private and public consumption must equalize their marginal rate of substitution in the representative consumer's utility function.

\section{The representative firm}

The representative firm in country $i$ produces with the input of two production factors, capital from domestic or foreign source and labor, whose respective shares in the production function are $(v)$ and $(1-v)$. We assume that marginal products are positive and diminishing and that all factors are complementary in the production function. In addition, public expenditure is also a factor that raises public input. Production increases with public goods and services supplied by the government in country $i$, according to the parameter $z$. Therefore, the production function of the country $i$ is as follows:

$$
Y_{i}=F_{i}\left(K_{i, i}+K_{j, i}, L_{i}\right)=A_{i}\left(K_{,, i}^{d}\right)^{v}\left(L_{i}\right)^{1-v} G_{i}^{z}
$$


where $\left(A_{i}\right)$ : productivity or technological shock.

The representative firm maximizes its real profit:

$$
\pi_{i}=Y_{i}-r_{i} K_{, i}^{d}-w_{i} L_{i}
$$

Production factors are paid at their marginal products, and we suppose constant returns. The maximization of the profit in Equation (8) implies:

$$
\begin{aligned}
& \frac{\partial \pi_{i}}{\partial K_{., i}^{d}}=\frac{\partial Y_{i}}{\partial K_{., i}^{d}}-r_{i}=0, \quad \frac{\partial Y_{i}}{\partial K_{., i}^{d}}=v A_{i}\left(K_{, i}^{d}\right)^{-(1-v)}\left(L_{i}\right)^{1-v} G_{i}^{z}=r_{i}>0 \\
& \frac{\partial \pi_{i}}{\partial L_{i}}=\frac{\partial Y_{i}}{\partial L_{i}}-w_{i}=0, \quad \frac{\partial Y_{i}}{\partial L_{i}}=(1-v) A_{i}\left(K_{,, i}^{d}\right)^{v}\left(L_{i}\right)^{-v} G_{i}^{z}=w_{i}>0
\end{aligned}
$$

Therefore, by combining Equations (9) and (10), we obtain the following relation between the real wage and the real interest rate in the country $i$ :

$$
w_{i}=\frac{(1-v) K_{, i}^{d}}{v L_{i}} r_{i}
$$

Second-order derivatives then imply:

$$
\frac{\partial^{2} Y_{i}}{\partial^{2} K_{,, i}^{d}}=\frac{\partial \mathrm{r}_{i}}{\partial K_{,, i}^{d}}=-v(1-v) A_{i}\left(K_{., i}^{d}\right)^{-(2-v)}\left(L_{i}\right)^{1-v} G_{i}^{z}<0
$$

Then, by combining Equations (4) and (9), we obtain

$$
\left(K_{i, i}^{d}+K_{j, i}^{d}\right)=\frac{v^{\frac{1}{(1-v)}}\left(A_{i}\right)^{\frac{1}{(1-v)}}\left(L_{i}\right)_{i}^{\frac{z}{(1-v)}}\left(1-t_{i}^{k}\right)^{\frac{1}{(1-v)}}}{\rho^{\frac{1}{(1-v)}}}
$$

And therefore, we have ${ }^{2}$ :

${ }^{2}$ With $\left(t_{i}^{k}=0.3\right)$ and $(v=0.33)$, this is consistent with an elasticity of: $\left(\frac{\partial\left(\mathrm{K}_{i, i}+K_{j, i}\right)}{\partial t_{i}^{k}} \frac{t_{i}^{k}}{\left(\mathrm{~K}_{i, i}+K_{j, i}\right)}\right)=-0.65$, near the one mentioned in the
following section III.D for the basic calibration of our parameters. 


$$
\frac{\partial\left(K_{i, i}+K_{j, i}\right)}{\partial t_{i}^{k}} \frac{t_{i}^{k}}{\left(K_{i, i}+K_{j, i}\right)}=-\frac{t_{i}^{k}}{(1-v)\left(1-t_{i}^{k}\right)}<0
$$

The tax elasticity of the demand for capital, i.e., the percentage change in the demand for capital in a given country in response to a $1 \%$ increase in its own capital tax rate, is negative. The larger (more negative) this value, the higher the national taxation rate. Therefore, tax evasion occurs because a higher taxation rate in a given country implies a leakage of the tax base. A higher taxation rate has consequences for the tax base in an open economy; an outflow of capital results if the taxation rate increases. Indeed, a higher taxation rate decreases the net marginal product in the national country and causes capital to relocate toward the remaining countries. This capital flow can then also reduce the marginal product of capital abroad. Another explanation is provided by the observation that in a small open economy, a source-based tax on capital income pushes up the required pre-tax rate of return, leaving the post-tax rate of return unaffected. Such a process usually requires a reduction in the stock of capital.

Furthermore, using Equations (4), (11) and (13), we obtain:

$$
\begin{gathered}
\frac{\partial\left(\mathrm{K}_{j, j}+K_{i, j}\right)}{\partial t_{i}^{k}} \frac{t_{i}^{k}}{\left(\mathrm{~K}_{j, j}+K_{i, j}\right)}=0 \\
w_{i}=\frac{(1-v) v^{\frac{v}{(1-v)}}\left(A_{i}\right)^{\frac{1}{(1-v)} G_{i}^{\frac{z}{(1-v)}}\left(1-t_{i}^{k}\right)^{\frac{v}{(1-v)}}}}{\rho^{\frac{v}{(1-v)}}} \\
\frac{\partial w_{i}}{\partial t_{i}^{k}} \frac{t_{i}^{k}}{w_{i}}=-\frac{v t_{i}^{k}}{(1-v)\left(1-t_{i}^{k}\right)}<0
\end{gathered}
$$

These equations indicate that the real wage falls in response to a higher capital taxation rate in the national country. Indeed, source-based capital income taxes raise the required pre-tax rate of return on capital, which means that at the margin the post-tax rate of return remains equal to the global rate of interest. In turn, such taxes tend to drive away capital and consequently depress wages or to reduce employment. Therefore, the labor force bears the 
effective outcomes of such taxation.

\section{The government and calibration of parameters}

The government of country $i$ finances public expenditure from its fiscal resources, e.g., taxes on labor and capital. For the moment, we suppose that the taxation rate on capital invested abroad (residence principle) is $\left(x_{i} \rho\right)$ in order to provide some scope for the various institutional and empirical arrangements decided by different countries. For example, $\left(x_{i}=0\right)$ in the framework of a tax exemption system where profits are only taxed in the country where production is realized. However, $x_{i}$ can also be positive in the framework of a tax credit system, e.g., when a credit is granted for taxes already paid in the foreign country at the origin of the production but there is still a residual tax to pay in the national residence country. Accordingly, we have the following budgetary constraint for the government of country $i$ :

$$
G_{i}=t_{i}^{k} r_{i} K_{i, i}+t_{i}^{k} r_{i} K_{j, i}+x_{i} \rho K_{i, j}+t_{i}^{l} w_{i} L_{i}
$$

The EUTAX model of Sorensen (2001) calibrates the share of capital in GDP as $(v=0.33)$, whereas Mendoza (2001) calibrates this share of capital as $(v=0.36)$. In keeping with these calibrations and the empirical data, we can then calibrate the share of capital in GDP as $(v=0.36)$. In the same way, according to empirical data, the global after-tax net return of capital is usually estimated at around $(\rho=12 \%)$.

Regarding taxation rates levels, Sorensen (2001) calibrates the effective tax rate on labor income at $\left(t_{i}^{l}=0.394\right)$ and the effective tax rate on capital income at $\left(t_{i}^{k}=0.371\right)$, in conformity with average EU values. Mendoza (2001) calibrates the tax rate on labor income at $\left(t_{i}^{l}=0.244\right)$ in the UK and $\left(t_{i}^{l}=0.474\right)$ in continental Europe. Similarly, Mendoza (2001) found the effective tax rate on capital income to be $\left(t_{i}^{k}=0.472\right)$ in the UK and $\left(t_{i}^{k}=0.280\right)$ in continental Europe.

Furthermore, De Mooij and Ederveen (2003) provide a meta-analysis on the differentials in results obtained by economic surveys regarding the sensibility of investment to capital taxation rates. Drawing upon a large data base, they conclude that capital flows to tax havens and capital flows by non- 
manufacturing firms which may contain much more financial capital are probably more responsive to taxes than real capital, which is in turn more responsive to taxes than mergers and acquisitions. The authors find huge differentials in the results of economic surveys. However, the mean value of the tax rate elasticity in the literature is around $-0.7 \%$, i.e., a $1 \%$ reduction in the host country's tax rate raises foreign direct investment in that country by $0.7 \%$. Hines (1999) also underlines empirically that the fiscal context influences investment location. He finds an elasticity of $-0.6 \%$, which he interprets as indicating that a $1 \%$ point increase in the foreign tax rate reduces US investment in a country by $0.6 \%$.

\section{Optimal Taxation Rates}

Are optimal capital taxation rates positive, or is there a risk that they could tend toward zero in a framework of tax competition? Bucovetsky and Wilson (1991) consider large regions, i.e., regions than can influence the after-tax return on capital. They find that these regions choose to tax capital at a positive rate (no race to the bottom until a level near zero) ${ }^{3}$ even if this rate is low. In other words, they assume that large regions choose a mix of taxes weighted more toward capital taxation. As long as competing regions exist, however, the chosen tax mix is inefficient due to the fiscal externalities resulting from a move toward a lower tax rate on capital, which implies a concomitant under-provision of public goods. Wilson (1991) also finds that small regions tend to set lower tax rates than large regions because the former have the higher capital elasticities. As a result, capital is misallocated across these regions even if capital taxation rates do not tend to be null. Given this background, what is the contribution of our own model?

The model described in the section III sheds a new light on optimal taxation rates in an open economy framework. Indeed, in this section, we suppose that in the monetary union, country $i$ is net capital importer $\left(K_{i, j}=0\right.$; $K_{j, i}>0$ ) and country $j$ is net capital exporter. This allow us to distinguish not only between countries' sizes, but also between types (capital-importing or capital-exporting). Appendixes A and B detail the determination of optimal

${ }^{3}$ This rate does not decline until zero, for example because of the properties of the production function: the elasticity of substitution between labor and capital is greater than labor's income share in production. 
taxation rates in both countries in a Nash equilibrium framework. Altshuler and Goodspeed (2015) are among the few authors who have departed from this context. They find that the European countries behave as if the US were a Stackelberg leader. However, in order to study fiscal relations among member countries of the EU, for example, a Nash equilibrium seems more appropriate and offers a better depiction of reality.

\section{A. Optimal taxation rates in the capital-importing country}

What are the optimal taxation rates in capital-importing country $i$ ? A first solution given by Equation (B5) in Appendix B is as follows:

$$
t_{i}^{k}=\frac{\left[v\left(\alpha_{c}-\alpha_{g}+2 v \alpha_{g}\right)(1-\rho) K_{i, i}-2 \alpha_{c}(1-v)^{2} \rho\left(K_{i, i}+K_{j, i}\right)\right]}{v\left[\left(\alpha_{c}-\alpha_{g}+2 v \alpha_{g}\right)(1-\rho) K_{i, i}+\left(3 \alpha_{c}-2 v \alpha_{c}+\alpha_{g}\right) \rho\left(K_{i, i}+K_{j, i}\right)\right]}
$$

However, this value is only possible if $\left(0<t_{i}^{k}<1\right)$, i.e., if:

$$
\frac{K_{i, i}}{K_{j, i}}>\frac{2 \alpha_{c}(1-v)^{2} \rho}{\left[v\left(\alpha_{c}-\alpha_{g}+2 v \alpha_{g}\right)(1-\rho)-2 \alpha_{c}(1-v)^{2} \rho\right]}>\frac{\rho(1-v)}{(v-\rho)} \quad \text { with } v<\frac{1}{2}
$$

A second solution of our optimization problem is given by Equation (B5) in Appendix B, which is as follows:

$$
\begin{cases}t_{i}^{k \prime}=0 & \text { if } \frac{K_{i, i}}{K_{j, i}}<\frac{\rho(1-v)}{(v-\rho)} \\ t_{i}^{k \prime}=\frac{\left[(v-\rho) K_{i, i}-\rho(1-v) K_{j, i}\right]}{v\left(K_{i, i}+\rho K_{j, i}\right)} & \text { if } \frac{K_{i, i}}{K_{j, i}}>\frac{\rho(1-v)}{(v-\rho)}\end{cases}
$$

However, according to the basic calibration of the parameters of our model, Equation (19) is empirically more plausible because taxation rates are higher with $\left(t_{i}^{k \prime}\right)$ in (21) and could prevent country $i$ from being attractive to capital investors. Therefore, we will retain and the solution of $\left(t_{i}^{k}\right)$ in Equation (19) for capital-importing country $i$.

Afterwards, replacing Equation (19) in Equation (B1) yields: 


$$
t_{i}^{l}=\frac{\left\{\rho(1-v)\left(2 \alpha_{c}+\alpha_{g}-2 v \alpha_{c}\right)\left(K_{j, i}+K_{i, i}\right)-(1-\rho)\left[\alpha_{c} v+\alpha_{g}\left(1-2 v+2 v^{2}\right)\right] K_{i, i}\right\}}{(1-v)\left[\left(\alpha_{c}-\alpha_{g}+2 v \alpha_{g}\right)(1-\rho) K_{i, i}+\left(3 \alpha_{c}-2 v \alpha_{c}+\alpha_{g}\right) \rho\left(K_{i, i}+K_{j, i}\right)\right]}
$$

However, this expression is negative if Equation (20) is verified and if $v<\frac{1}{2}$.

In the same way, replacing Equation (21) in Equation (B1) produces:

$$
t_{i}^{l \prime}=-\frac{\left[(v-\rho) K_{i, i}-\rho(1-v) K_{j, i}\right]}{(1-v)\left(K_{i, i}+K_{j, i}\right)}
$$

However, this expression is negative if $\left(t_{i}^{k^{\prime}}>0\right)$.

Therefore, Equation (B1) implies:

$$
\begin{cases}t_{i}^{l}=t_{i}^{l \prime}=\frac{\alpha_{g}\left[(\rho-v) K_{i, i}+\rho(1-v) K_{j, i}\right]}{\left(\alpha_{c}+\alpha_{g}\right) \rho(1-v)\left(K_{i, i}+K_{j, i}\right)} & \text { if } \frac{K_{i, i}}{K_{j, i}}<\frac{\rho(1-v)}{(v-\rho)} \\ t_{i}^{l}=t_{i}^{l \prime}=0 & \text { if } \frac{K_{i, i}}{K_{j, i}}>\frac{\rho(1-v)}{(v-\rho)}\end{cases}
$$

We can make the hypothesis that the size of a country is an increasing function of its national capital stock in comparison with the capital stock due to foreign investment $\left(\frac{K_{i, i}}{K_{j, i}}\right)$. Therefore, if this capital importing country $i$ is large relative to the partner country in the monetary union, it can set a higher taxation rate without such a move harming its own national production because the share of foreign capital in the production function $K_{j, i}$ is relatively weak. The capital taxation rate in a capital-importing country is an increasing function of that country's relative size $\left[\frac{\partial t_{i}^{k^{\prime}}}{\partial\left(\frac{K_{i, i}}{K_{j, i}}\right)}>0 ; \frac{\partial t_{i}^{k}}{\partial\left(\frac{K_{i, i}}{K_{j, i}}\right)}>0\right.$ if $\left.\left(\alpha_{c}-\alpha_{g}+2 v \alpha_{g}\right)>0\right]$.

Our result is therefore in line with the tax competition literature, which points out that small countries set lower capital taxation rates than large countries. Indeed, Keen and Konrad (2013) explain that small countries can attract more capital relative to their own size by reducing their tax rate. ${ }^{4}$ This

${ }^{4}$ Nevertheless, Hines (2007) mentions that the positive correlation between a country's size and its capital taxation rate, a finding empirically verified in 1982 and strongly narrowed in 1999. 
theoretical result can explain why the small EU countries like Lithuania $(12.5 \%)$, Estonia (12.6\%), Slovakia (15.4\%) or Latvia (17.6\%), have weaker capital taxation rates, whereas these rates are higher in big capital importing countries like Poland (21.6\%), Portugal (26\%) or Spain $(29.1 \%)^{5}$ . Furthermore, higher capital taxation rates then allow large countries to set weaker labor taxation rates $\left(\frac{\partial t_{i}^{l}}{\partial\left(\frac{K_{i, i}}{K_{j, i}}<\right.}<0\right)$ for the same level of fiscal resources. Conversely, the fiscal weight on the labor production factor would be stronger in small capital-importing countries.

More precisely, according to our theoretical model, taxation of capital $\left(t_{i}^{k}\right.$ $>0)$ is possible only if $\left(\frac{K_{i, i}}{K_{j, i}}\right)$ is above a given value, i.e., if capital-importing country $i$ is sufficiently large so that the share of capital in the production function from domestic sources in this country must be $0.72\left(0.39\right.$ for $t_{i}^{k \prime}$ ) times the capital from foreign sources, according to our basic calibration. Therefore, the risk of a race to the bottom regarding capital taxation at zero taxation rates would only concern the smallest countries. 
Figure 1. Optimal capital and labor taxation rates in the capital-importing country $i$

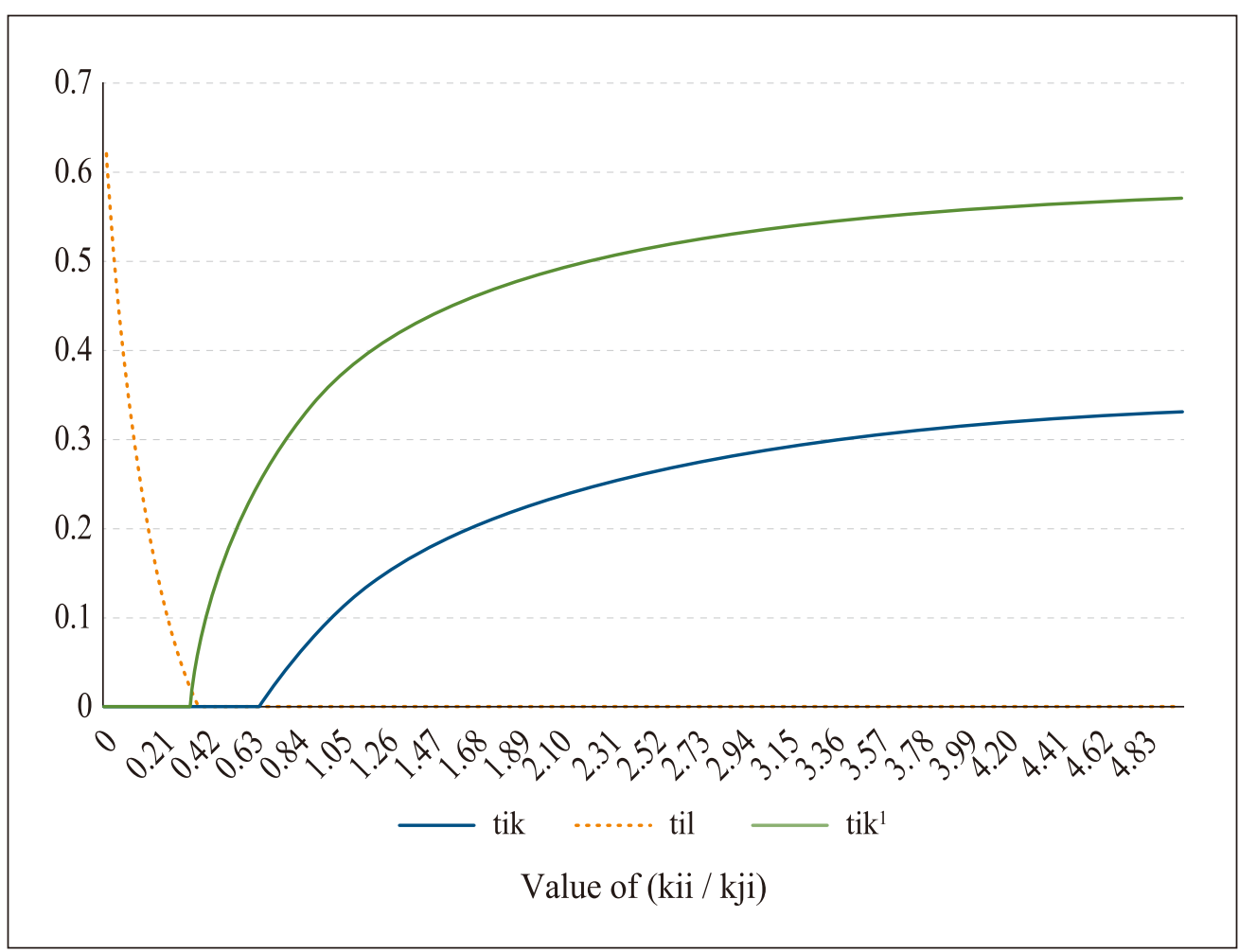

(Note) Calibration: $\alpha_{c}=3 ; \alpha_{g}=1 ; \rho=0.12 ; \nu=0.33$

The optimal capital taxation rate also increases with the representative consumer's relative preference for private rather than public consumption for plausible values of our parameters $\left[\frac{\partial t_{i}^{k}}{\partial\left(\frac{\alpha_{c}}{\alpha_{g}}\right)}>0\right.$ if: $\left.(1-2 \rho) K_{i, i}>\rho K_{j, i}\right]$. Indeed, a higher capital taxation rate reduces the capital fiscal base that can be attracted to capital-importing country $i$. However, this situation is not detrimental if economic agents favor private over public consumption, thus favoring a higher return for their sparing more than to benefit from more numerous public goods and services. Indeed, if the capital stock decreases in country $i$, such a reduction can contribute to increasing the relative productivity of the capital production factor. On the contrary, the labor taxation rate is increased by the representative consumer's relative preference for public services $\left[\frac{\partial t_{i}^{l}}{\partial\left(\frac{\alpha_{c}}{\alpha g}\right)}<0\right.$ if $\left.t_{i}^{l}>0\right]$, which increases the necessity to raise a sufficient level of 
fiscal resources in order to provide this level of public services.

Furthermore, in capital-importing country $i$, the capital taxation rate should also decrease with the global capital rate of return $\left[\frac{\partial t_{i}^{k \prime}}{\partial \rho}<0 ; \frac{\partial t_{i}^{k}}{\partial \rho}<0\right.$ if: $\left.\left(\alpha_{c}-\alpha_{g}+2 v \alpha_{g}\right)>0\right]$ because the latter increases the necessary and required post-tax rate of return on an investment. In parallel, the labor taxation rate should then rise $\left(\frac{\partial t_{i}^{l}}{\partial \rho}>0\right)$ in order to maintain the level of fiscal resources. Finally, the capital taxation rate should increase $\left[\frac{\partial t_{i}^{k \prime}}{\partial v}>0 ; \frac{\partial t_{i}^{k}}{\partial v}>0\right.$ if $\left.:\left(\alpha_{c}-\alpha_{g}+2 v \alpha_{g}\right)>0\right]$ with the capital share in the production function $(v)$. A higher capital share increases the fiscal base related to capital, and the capital taxation rate should then increase whereas the labor taxation rate should be reduced $\left(\frac{\partial t_{i}^{l}}{\partial v}<0\right)$. Indeed, taxing the capital production factor then becomes a more efficient approach to collect fiscal resources.

\section{B. Optimal taxation rates in the capital-exporting country}

The next question to be answered is what are the optimal taxation rates in capital-exporting country $j$ ?

In countries adopting a tax exemption for foreign-source capital income $\left(x_{j}=0\right)$, Equation (B10) in Appendix B implies:

$$
t_{j}^{k}=1-\frac{\rho\left(2 \alpha_{c}-v \alpha_{c}+v \alpha_{g}\right) K_{j, j}}{v\left[\alpha_{c}(1+2 \rho-2 v \rho) K_{j, j}-2(1-v) \alpha_{g}(1-\rho) K_{j, i}-\alpha_{g}(1-2 v-2 \rho+2 \rho v) K_{j, j}\right]}
$$

The capital taxation rate can then have a plausible value $\left(0<t_{j}^{k}<1\right)$ only if :

$$
\delta=\alpha_{c}\left(v+3 v \rho-2 v^{2} \rho-2 \rho\right) K_{j, j}-\alpha_{g} v(1-\rho)\left[2(1-v) K_{j, i}+(1-2 v) K_{j, j}\right]>0
$$

Therefore, taxing capital is only possible if private consumption is much more valuable for the representative consumer than public consumption $\left(\alpha_{c}>\right.$ $\left.\alpha_{g}\right)$. Furthermore, it is also necessary that $\left(K_{j, j}>K_{j, i}\right)$, such that even in capitalexporting country $j$, capital invested in the national country remains sufficient and higher than the amount invested in the foreign country. This situation is thus well-suited to represent the case of big countries. 
According to Equation (25), the capital taxation rate in capital-exporting country $j$ should increase with the relative size of the country $\left(\partial t_{j}^{k} / \partial\left(\frac{K_{j, j}}{K_{j, i}}\right)>0\right)$. Indeed, according to the basic calibration of our parameters, the capital taxation rate is around $\left(t_{j}^{k}=0.3 \%\right)$ if the capital invested in the national country is about 2.3 times as much as that exported to the foreign country. However, this rate does not exceed $\left(t_{j}^{k}=0.39 \%\right)$ even if the capital invested in the national country is 10 times higher than the amount exported $\left(K_{j, j}=\right.$ $\left.10 K_{j, i}\right)$.

Figure 2. Optimal capital taxation rate in capital-exporting country $\boldsymbol{j}$

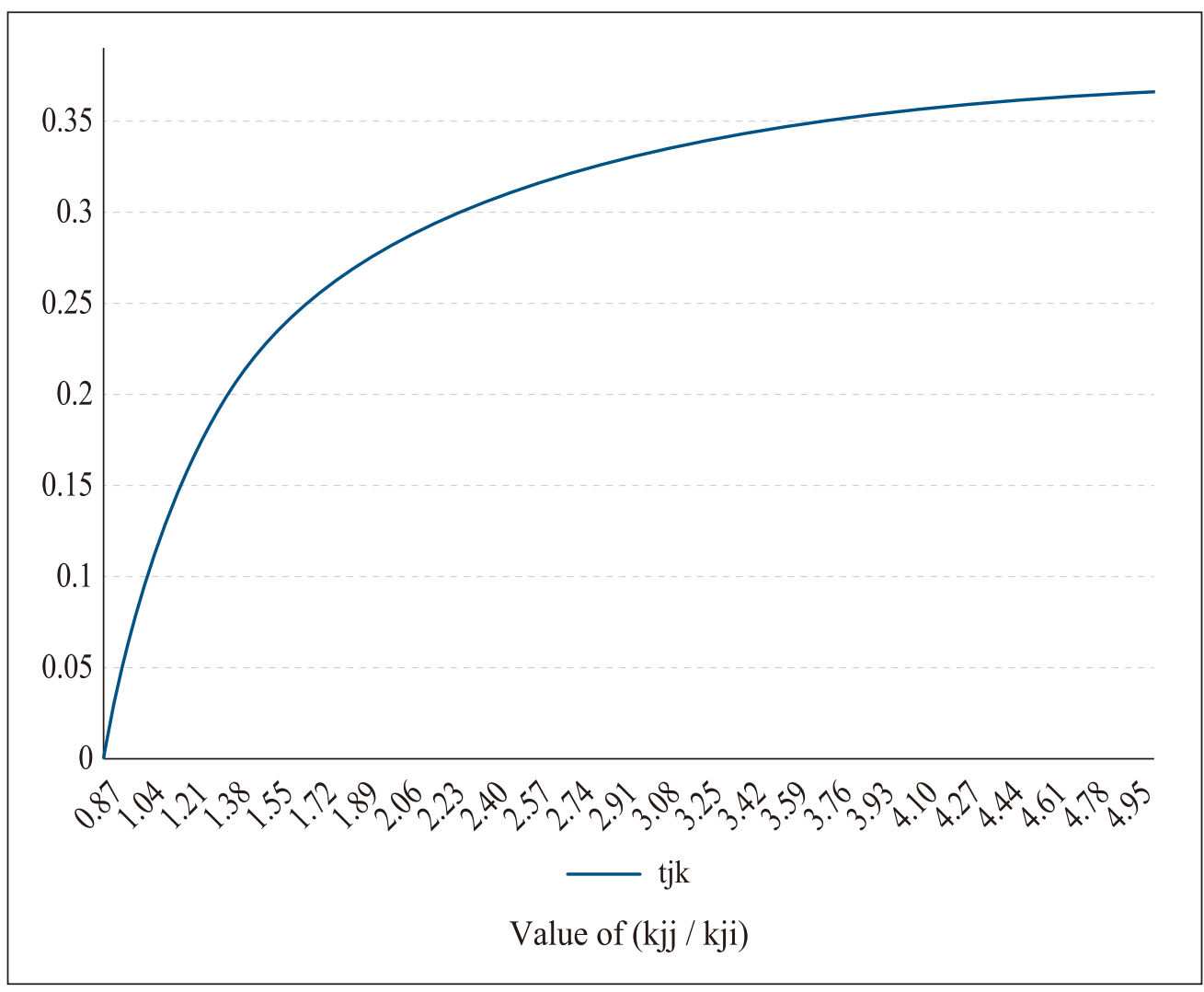

(Note) Calibration $\alpha_{c}=3 ; \alpha_{g}=1 ; \rho=0.12 ; \nu=0.33(\delta>0)$

Therefore, in terms of the capital importing country studied in section IV. A, we find that there is a risk of race to the bottom and of a zero capital taxation rate for the smallest capital exporting countries, whereas such a risk 
does not exist for big countries given their ability to sustain higher taxation rates. In the EU, for example, small countries like Luxembourg $(6.8 \%)$ or the Netherlands (14.4\%) have weaker capital taxation rates, whereas these rates are higher in big capital exporting countries like Germany (26\%), Italy (32\%) and mostly France (52.8\%).

The capital taxation rate also increases with $\left(\alpha_{c} / \alpha_{g}\right)$ for plausible values of our parameters. Indeed, a higher capital taxation rate in capital-exporting country $j$ implies leakage of the capital fiscal base. This is not detrimental if economic agents favor private rather than public consumption and thus prioritize a higher return for their sparing over the benefit they would receive from public goods and services. Indeed, a decline in the capital stock in country $j$ could contribute to increasing the relative productivity of the capital production factor.

Furthermore, if share of capital in the production function increases, the capital fiscal base increases, making it therefore optimal to tax capital more than labor $\left(\frac{\partial t_{j}^{k}}{\partial v}>0\right.$ for plausible values). Finally, a higher average global capital return $(\rho)$ increases the required and necessary post-tax rate of return on any investment. Therefore, the taxation rate in capital-exporting country $j$ should be reduced $\left[\frac{\partial t_{j}^{k}}{\partial \rho}<0\right.$ if $\left(\alpha_{c}\right)$ is reasonably high in comparison with $\left.\left(\alpha_{g}\right)\right]$.

Regarding the labor taxation rate, our theoretical model indicates that taxing the labor production factor is useful only if average global capital returns are very high in comparison with the share of capital in the production function $(\rho>v)$. Therefore, this situation is empirically quite implausible, and it is not in conformity with the basic calibration of our model's parameters. Indeed, we obtain:

$$
\begin{cases}t_{j}^{l}=\frac{\alpha_{g}\left[(\rho-v) K_{j, j}-(1-\rho) v K_{j, i}\right]}{\left(\alpha_{c}+\alpha_{g}\right) \rho(1-v) K_{j, j}} & \text { if } \frac{K_{j, j}}{K_{j, i}}>\frac{(1-\rho) v}{(\rho-v)}>06 \\ t_{j}^{l}=0 & \text { if } \quad 0<\frac{K_{j, j}}{K_{j, i}}<\frac{(1-\rho) v}{(\rho-v)}\end{cases}
$$

More precisely, in the second component of Equation (26), there are two situations: 
- Either $0<\frac{K_{j, j}}{K_{j, i}}<\frac{(1-\rho) v}{(\rho-v)}$ and $\rho>\frac{v}{\left(2-3 v+2 v^{2}\right)}$; then, we have $\left(t_{j}^{l}=0\right)$ and the previous conditions also implies $(\delta<0)$, and $\left(t_{j}^{k}=0\right)$

- Or $0<\frac{K_{j, j}}{K_{j, i}}<\frac{(1-\rho) v}{(\rho-v)}$ and $(\delta>0)$;

Then, substituting Equation (25) for $\left(t_{j}^{k}\right)$ in Equation (B6) in Appendix B, we obtain:

$$
\begin{gathered}
t_{j}^{l}=-\frac{\alpha_{g}\left[(1-2 v-2 \rho+3 \rho v+2 v v-2 \rho v v) K_{j, j}+(1-\rho)\left(2-3 v+2 v^{2}\right) K_{j, i}\right]}{(1-v)\left[\alpha_{c}(1+2 \rho-2 v \rho) K_{j, j}-2(1-v) \alpha_{g}(1-\rho) K_{j, i}-\alpha_{g}(1-2 v-2 \rho+2 \rho v) K_{j, j}\right]} \\
-\frac{\alpha_{c}\left(v+3 \rho v-2 v^{2} \rho-2 p\right) K_{j, j}}{(1-v)\left[\alpha_{c}(1+2 \rho-2 v \rho) K_{j, j}-2(1-v) \alpha_{g}(1-\rho) K_{j, i}-\alpha_{g}(1-2 v-2 \rho+2 \rho v) K_{j, j}\right]}
\end{gathered}
$$

However, $(\delta>0)$ and $\left(t_{j}^{k}>0\right)$ then imply $\left(t_{j}^{l}<0\right)$, and capital and labor taxation rates cannot be both positive.

According to Equation (B10) in Appendix B, a second solution to our optimization problem exists. Indeed, according to Equation (B10), the optimal capital taxation rate in capital-exporting country $j$ can also be:

$$
t_{j}^{k \prime}=\frac{\left[v\left(1-\rho-\rho x_{j}\right) K_{j, i}+(v-\rho) K_{j, j}\right]}{v\left[\left(1-\rho-\rho x_{j}\right) K_{j, i}+K_{j, j}\right]}
$$

This solution is possible $\left(0<t_{j}^{k}<1\right)$ as soon as $\left(1-\rho-\rho x_{j}\right) K_{j, i}+(v-\rho)$ $K_{j, j}>0$

Then, including Equation (28) in Equation (B6) in Appendix B, the optimal labor taxation rate in capital-exporting country $j$ is then:

$$
t_{j}^{l \prime}=-\frac{\left[(v-\rho) K_{j, j}+\left(v-v \rho+\rho x_{j}-v \rho x_{j}\right) K_{j, i}\right]}{(1-v)\left[K_{j, j}+\left(1-\rho-\rho x_{j}\right) K_{j, i}\right]}
$$

Therefore, taxing the labor production factor in parallel to capital is impossible because $\left(t_{j}^{l \prime}\right)$ in Equation (29) is negative if $\left(t_{j}^{k \prime}>0\right)$. This means 
that our result here is the same as that of Equation (24): fin the framework of our theoretical model, a positive labor taxation rate in both capital-exporting and capital-importing countries is only possible (and in this case, labor is the optimal fiscal base and the taxation rate on capital is null) in very laborintensive industries when the share of capital in the production function is weaker than the average global capital return $(v<\rho)$. For example, with the basic calibration of our model's parameters, if $\left(\rho x_{j}\right)$ is nearly null, the share of capital in the production function should be below a very limited value (about $10 \%$ ) in order to allow a positive labor taxation rate. However, the economic calibration usually considers that in industrialized countries, the capital share in the production function is around $(v=0.33)$. Therefore, for the most common capital-intensive industries, capital taxation rates allow to obtain enough fiscal resources. In capital-exporting countries, labor taxation rates should increase with the weight of the labor factor, whereas capital taxation rates should increase with the weight of the capital factor $\frac{\partial t_{j}^{k \prime}}{\partial v}>0$ and $\frac{\partial t_{j}^{l \prime}}{\partial v}<0$ in the production function. Indeed, a country should increase the taxation rate on the production factor with the broader fiscal base.

Another implication of our model is that with the second solution $\left(t_{j}^{k \prime}\right)$ of our optimization problem mentioned in Equation (28), if the relative size of capital-exporting country $j$ increases and if a higher share of capital is invested in national industries in comparison with the share of exported capital, both the capital stock of country $j$ and the fiscal base increase. This means that the capital taxation rate could be reduced in capital-exporting country $j,\left[\frac{\partial t_{j}^{k_{j}^{\prime \prime}}}{\partial\left(\frac{K_{j, j}}{K_{j, i}}\right)}<0\right.$ for plausible values of $\left.\rho\right]$ for a same level of fiscal resources and public expenditure corresponding to the representative consumer's preferences. 
Figure 3. Optimal capital taxation rate in

\section{high-tax capital-exporting country $j$}

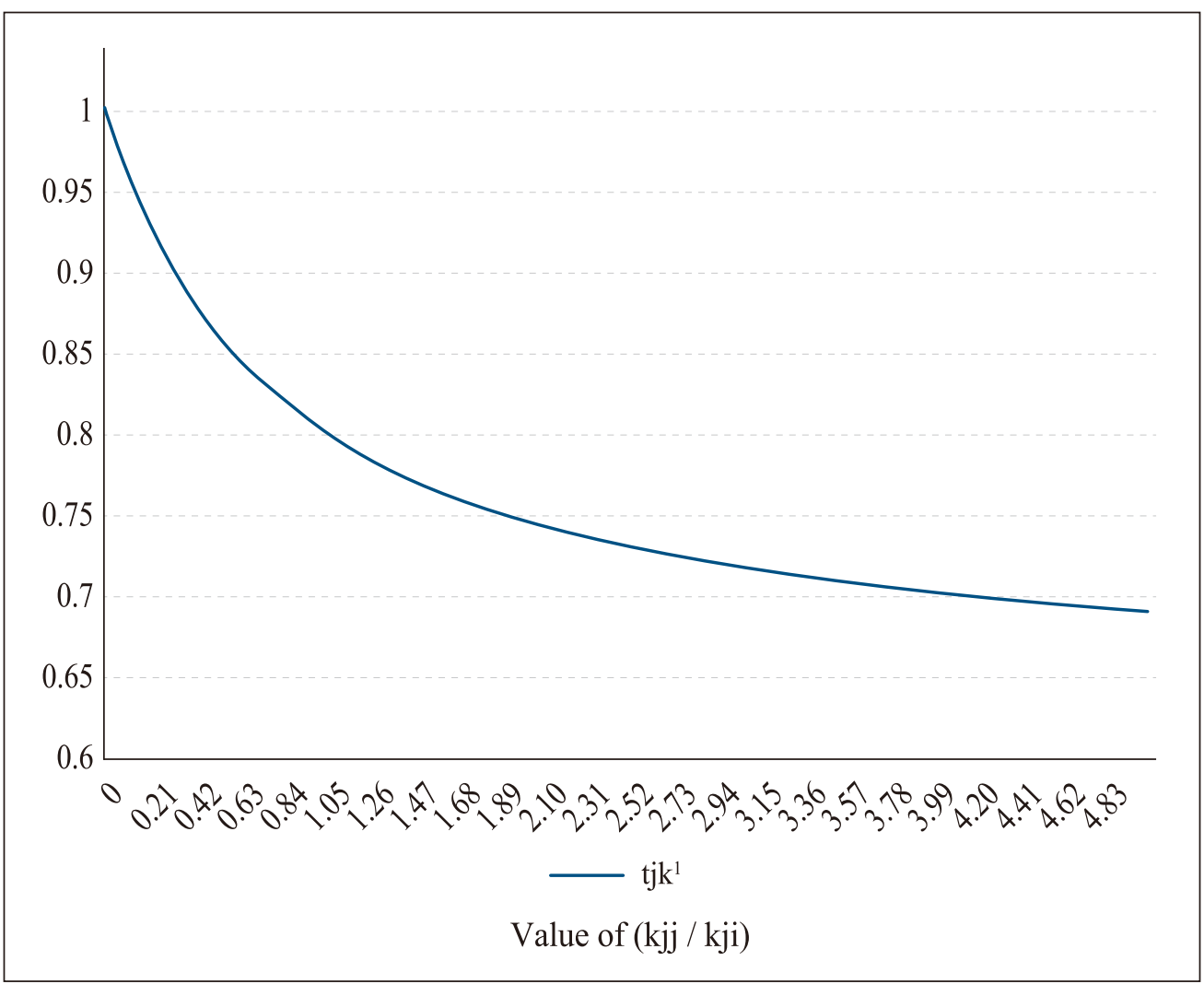

(Note) Calibration: $\rho=0.12 ; v=0.33 ; \rho x_{j}=0$

Nevertheless, taxation rates implied by Equation (28) are excessively high; they correspond to levels prohibitive for investors, who prefer to invest in foreign countries. Therefore, we will retain the more empirically plausible values of optimal capital taxation rates in capital-exporting country $j$ mentioned in Equation (25).

\section{Fiscal Externalities Regarding Capital Taxation Rates}

The previous section defined optimal capital taxation rates in capitalimporting and capital-exporting member countries of a monetary union. 
However, regarding tax competition between countries, an important question is whether tax rates are strategic complements or substitutes. In the former case, tax reaction functions have a positive slope, i.e., a jurisdiction will also lower (increase) its tax rate when tax rates of neighboring jurisdictions are falling (increasing) in order to avoid leakage of its tax base. Public expenditure levels may then be endogenously fixed at a weaker level. In contrast, if tax rates are strategic substitutes, a country facing decreasing tax rates in neighboring countries, and hence, a declining tax base due to relocation of mobile factors, would increase its tax rate in order to maintain a given level of public expenditure. If public expenditure is exogenously given as strategic variable, the tax reaction function can then have a negative slope. We will first mention the results of the economic literature regarding fiscal externalities before presenting the outcomes and implications of our own model.

\section{A. The economics literature}

Many papers have estimated tax reaction functions and introduced the weighted average tax rate of competing countries. Indeed, Wildasin (2002) mentions that governments may choose to explicitly coordinate their tax rates and fix them at given levels. However, in absence of such explicit decisions, implicit coordination may also happen if countries choose their fiscal policy according to a neighbor country's policy. This situation is similar to that of fiscal competition, whereby countries' taxation rate reaction functions depend on foreign taxation rates.

Therefore, in the context of various local jurisdictions in the same country, Brueckner (2003) notes that the slope of a local government's tax reaction function is theoretically ambiguous in terms of sign. For example, if neighboring jurisdictions lower their tax rates, the standard tax competition argument implies that the local government should react by lowering its own tax rate, i.e., positively sloped reaction function. However, the capital outflow induced by rate reductions in other jurisdictions implies a reduction in revenues and, if local preferences for public services are sufficiently strong, the local tax rate could in fact increase. Nevertheless, Brueckner (2003) also points out that in virtually all empirical studies analyzed, the estimated tax reaction function confirms the existence of strategic interaction and is upward 
sloping, indicating that traditional tax competition factors dominate.

Cassette and Paty (2008) investigate the strategic interactions between the former EU15 countries and Central and Eastern European countries regarding corporate taxes. Using the econometric Generalized Moments Method, they estimate the strategic interactions among 27 European countries in the 1995 2005 period. They first confirm that European countries seem to follow leaders regarding population size and economic characteristics (performance in attracting FDI) when setting corporate tax choices. However, their results indicate that strategic interactions among Eastern European countries are rather sparse. Finally, they show the existence of some tax interactions between these two regions of Europe. These interactions seem to depend on relative economic characteristics such as relative per-capita GDP, that is, economic weight and FDI attraction.

In the same way, Redoano (2007) models capital tax competition between countries that differ in spatial location and where cross-border investment costs are proportional to distance (a gravity model), but also to EU membership, which facilitates access to the internal market. The author models EU membership as a reduction in distance between countries. He finds that all EU countries react more to member countries than to nonmembers. These theoretical results are confirmed by the empirical analysis on statutory corporate tax rates of Western European countries during the 1970 1999 period.

We can now discuss some empirical studies that find that fiscal externalities among countries are mainly positive. For example, Buettner (2001) discusses capital income taxation between asymmetric jurisdictions when tax revenue is used to provide productive government expenditures. He analyses empirically collection rates of the local business tax in Germany between 1980 and 1996. He finds that competition between interdependent jurisdictions does exist, but such competition does not eliminate all tax differentials between districts. Indeed, tax rates are positively related to neighbors' tax rates. However, they are also positively related to the community's population size and to the share of local welfare recipients.

Devereux et al. (2008) investigate tax competition by estimating tax reaction functions in terms of multinationals' investment decisions using data from 21 OECD countries between 1982 and 1999. With regard to corporate taxes, they show that industrialized countries clearly compete over 
the statutory tax rate and effective average tax rate. Specifically, the authors estimate that a one-percentage-point reduction in the weighted average statutory tax rate in other countries results in a 0.7 percentage-point reduction in the home country's tax rate. Moreover, countries appear to react more strongly to changes in other countries' tax rates when their own tax rate is above average. Finally, they find weak evidence that governments react to other countries' effective marginal tax rates. This competition occurs over the statutory tax rate and tax base (stock of capital).

In the same way, Davies and Voget (2010) empirically examine whether the EU expansion increased international tax competition. They use a simple model of tax competition to determine how a given country weights other countries' taxes when choosing its own taxes. They use a complex system based on each country's market power, depending on population size and domestic market as well as gross exports and access to foreign markets, in order to define the weight of each partner country in the regression. They find that more open countries and countries with higher market power tend to have higher taxation rates. They further find robust evidence for tax competition between 1980 and 2005. In particular, their estimates suggest that EU membership affects responses, with EU members responding more to the tax rates of other members. This suggests that expanding the EU to include the low-cost Eastern countries could force Western nations to respond to those new-accession countries' tax regimes.

Altshuler and Goodspeed (2015) also find that EU countries use corporate taxes to strategically compete with geographically close countries, i.e., positive slope for Nash tax reaction functions, but not labor taxes. Their main finding, however, is that European countries behave as if the US were a Stackelberg leader by reducing their own corporate tax rates after the US implemented the 1986 Tax Reform Act. In the same way, using comprehensive data on corporate tax reforms in 32 European countries between 1980 and 2007, Heinemann et al. (2008) empirically show that the probability for tax rate reductions among European countries strongly depends on a country's relative position in terms of the tax burden on corporate income. In particular, high-tax countries or countries undergoing election campaigns are significantly more likely to reduce their tax rates. According to the authors, countries are particularly likely to cut their statutory tax rate if the inherited tax is high and if they are exposed to low- 
tax neighbors. If tax rates are on a decreasing trend in foreign countries, for example with the accession of Eastern European countries.

This discussion of the literature has highlighted that the empirical evidence usually points toward positively sloped tax reaction functions. However, de Mooij and Vrijburg (2012) show that tax rates are strategic complements only if public and private goods are close substitutes as assumed in standard models, but that they are strategic substitutes, i.e., negative slope of the tax reaction function, if public and private goods are close complements. Indeed, the authors argue that the slope of the tax reaction function is negative, or strategic substitutability, in a classical capital tax competition model where countries maximize welfare under relatively mild conditions for the parameters of the model. This strategic substitutability is more likely to exist if the country is capital exporter. Therefore, this result implies that in the context of strategic substitutability, formation of a tax union might reduce welfare for union-member countries. Indeed, an adverse response -higher taxes abroad if the national taxation rate is reduced- by the foreign country may offset the benefits of forming the union.

In the same way, Parchet (2013) use a multi-tier federal system and finds that for local tax setting in Switzerland, tax rates are strategic substitutes in most cases. Indeed, a jurisdiction that faces a decrease in its tax base through a more competitive environment will increase its tax rate to maintain its current level of expenditure even at the expense of a further adverse effect on its tax base. Tax rates would only be strategic complements in the context of large tax cuts. In an attempt to retain its mobile tax base, a jurisdiction will lower its tax rate only when tax rates in neighboring jurisdictions fall strongly, that is, positive tax slope.

Finally, other characteristics of the modelling also imply a negative slope of the tax reaction function. Chirinko and Wilson (2017) stress that the slope of the tax reaction function depends on the sign of one key parameter income elasticity of public goods relative to private goods. However, they also show that delays in tax policy adjustments to shocks and heterogeneous responses to aggregate shocks may explain why the slope of the tax reaction function turn negative. In this context, they analyze empirically the reaction of capital tax policy in a given the US state to changes in other states' capital tax policies between 1965 and 2006. They find that the slope of the reaction function is unexpectedly negative. The secular decline in capital tax rates 
would only reflect synchronous responses among states to common shocks rather than competitive responses to a foreign state's tax policy. Therefore, no race to the bottom would occur, and policies aimed at restricting tax competition to stem the tide of declining capital taxation rates are likely to be ineffective.

Given the ambiguous sign of fiscal externalities mentioned in the economic literature, what could our own theoretical model imply?

\section{B. Implications of our model}

The model presented in sections III and IV allows us to obtain new results regarding fiscal externalities for capital taxation rates even in a static framework. In particular, we can distinguish between the cases of a large capital-exporting or small capital-importing country. Regarding the capital taxation rate in capital-exporting country $j$, combining Equations (19) and (25) yields:

$$
\begin{gathered}
t_{j}^{k}=\frac{\lambda_{i, j}^{(1)}}{\lambda_{i, j}^{(2)}} \\
\lambda_{i, j}^{(1)}=\alpha_{c}\left[v\left(3 \alpha_{c}-2 v \alpha_{c}+\alpha_{g}\right) t_{i}^{k}+2 \alpha_{c}(1-v)^{2}\right] \rho\left(v+3 \rho v-2 v^{2} \rho-2 p\right) K_{j, j} \\
-v \alpha_{g}(1-2 v-\rho+2 \rho v)\left[v\left(3 \alpha_{c}-2 v \alpha_{c}+\alpha_{g}\right) t_{i}^{k}+2 \alpha_{c}(1-v)^{2}\right] \rho K_{j, j} \\
-2 v^{2}(1-v) \alpha_{g}(1-\rho)\left[\left(\alpha_{c}-\alpha_{g}+2 v \alpha_{g}\right)+2\left(\alpha_{c}+\alpha_{g}\right)(1-v) \rho\right]\left(1-t_{i}^{k}\right) K_{i, i} \\
+2 v(1-v) \alpha_{g}(1-\rho)\left(2 \alpha_{c}-v \alpha_{c}+v \alpha_{g}\right) \rho K_{i, i} \\
\lambda_{i, j}^{(2)}=\alpha_{c}\left[v\left(3 \alpha_{c}-2 v \alpha_{c}+\alpha_{g}\right) t_{i}^{k}+2 \alpha_{c}(1-v)^{2}\right] \rho v(1+2 \rho-2 v \rho) K_{j, j} \\
-v \alpha_{g}(1-2 v-2 \rho+2 \rho v)\left[v\left(3 \alpha_{c}-2 v \alpha_{c}+\alpha_{g}\right) t_{i}^{k}+2 \alpha_{c}(1-v)^{2}\right] \rho K_{j, j} \\
-2 v^{2}(1-v) \alpha_{g}(1-\rho)\left[\left(\alpha_{c}-\alpha_{g}+2 v \alpha_{g}\right)+2\left(\alpha_{c}+\alpha_{g}\right)(1-v) \rho\right]\left(1-t_{i}^{k}\right) K_{i, i} \\
+2 v(1-v) \alpha_{g}(1-\rho)\left(2 \alpha_{c}-v \alpha_{c}+v \alpha_{g}\right) \rho K_{i, i}
\end{gathered}
$$

Equation (31) thus implies:

$$
\frac{\partial t_{j}^{k}}{\partial t_{i}^{k}}=\frac{2 v^{2}(1-v)(1-\rho)^{2} \rho^{2} \alpha_{g}\left(2 \alpha_{c}-v \alpha_{c}+v \alpha_{g}\right)^{2}\left(\alpha_{c}-\alpha_{g}+2 v \alpha_{g}\right) K_{i, i} K_{j, j}}{\lambda_{i, j}^{(2) 2}}
$$


Accordingly, as in Buettner (2001) for example and in keeping with most of the empirical results mentioned in section V. A, fiscal externalities are positive $\left(\frac{\partial t_{j}^{k}}{\partial t_{i}^{k}}>0\right)$ as soon as the representative consumer's preference for private consumption is sufficiently high. Chirinko and Wilson (2017) also stress that the slope of the tax reaction function depends on the sign of one key parameter income elasticity of public goods relative to private goods. The sign on this elasticity is related to whether private goods are necessities or luxuries in terms of the preferences of economic agents. However, our analytical model contributes by providing an accurate analytical condition for the preferences of these economic agents in order to have positive externalities: $\left[\alpha_{c}>(1-2 v) \alpha_{g}\right]$.

Indeed, if the capital taxation rate decreases in the other country, the capital-exporting country $j$ will usually decreases its own capital taxation rate as well in order to avoid leakage of its capital fiscal base out of the country. For example, in the EU, we can observe that the implicit capital taxation rate has been reduced since the 1990's in Germany or in the Netherlands, after the introduction of new Eastern European countries with weaker capital taxation rates in the Euro Area (European Commission 2018).

Nevertheless, our model also shows that there is a situation where fiscal externalities can be negative $\left(\frac{\partial t_{j}^{k}}{\partial t_{i}^{k}}<0\right)$. This occurs when the representative consumer's preferences for public goods consumption is particularly high: about three times higher than the preference for private goods according to our basic calibration. Indeed, in the latter case, a weaker foreign capital taxation rate implies a leakage of the fiscal base and a loss of fiscal revenues for capital-exporting country $j$. Therefore, the capital taxation rate in this country should increase in order to collect a sufficient level of fiscal resources to provide the high level of public goods and services desired by the representative consumer.

In the same way, regarding the capital taxation rate in capital-importing country $i$, combining Equations (19) and (25) yields: 


$$
\begin{gathered}
t_{i}^{k}=\frac{\lambda_{i, j}^{(3)}}{\lambda_{i, j}^{(4)}} \\
\lambda_{i, j}^{(3)}=2 v(1-v) \alpha_{g}(1-\rho)\left(1-t_{j}^{k}\right)\left[v\left(\alpha_{c}-\alpha_{g}+2 v \alpha_{g}\right)(1-\rho)-2 \alpha_{c}(1-v)^{2} \rho\right] K_{i, i} \\
-2 v \alpha_{c}(1-v)^{2} \rho\left[\left(\alpha_{c}+\alpha_{g}\right)(1+2 \rho-2 v \rho)-2 \alpha_{g}(1-v)\right]\left(1-t_{j}^{k}\right) K_{j, j} \\
+2 \rho^{2}\left(2 \alpha_{c}-v \alpha_{c}+v \alpha_{g}\right) \alpha_{c}(1-v)^{2} K_{j, j} \\
\lambda_{i, j}^{(4)}=2 v^{2}(1-v) \alpha_{g}(1-\rho)\left(1-t_{j}^{k}\right)\left[\left(\alpha_{c}-\alpha_{g}+2 v \alpha_{g}\right)+2\left(\alpha_{c}+\alpha_{g}\right)(1-v) \rho\right] K_{i, i} \\
+v^{2}\left(3 \alpha_{c}-2 v \alpha_{c}+\alpha_{g}\right) \rho\left[\left(\alpha_{c}+\alpha_{g}\right)(1+2 \rho-2 v \rho)-2 \alpha_{g}(1-v)\right]\left(1-t_{j}^{k}\right) K_{j, j} \\
-\rho^{2} v\left(3 \alpha_{c}-2 v \alpha_{c}+\alpha_{g}\right)\left(2 \alpha_{c}-v \alpha_{c}+v \alpha_{g}\right) K_{j, j}
\end{gathered}
$$

Equation (33) implies:

$$
\frac{\partial t_{i}^{k}}{\partial t_{j}^{k}}=\frac{2 v^{2}(1-v)(1-\rho)^{2} \rho^{2} \alpha_{g}\left(2 \alpha_{c}-v \alpha_{c}+v \alpha_{g}\right)^{2}\left(\alpha_{c}-\alpha_{g}+2 v \alpha_{g}\right) K_{i, i} K_{j, j}}{\lambda_{i, j}^{(4) 2}}
$$

This result is exactly the same. Fiscal externalities are positive $\left(\frac{\partial t_{i}^{k}}{\partial t_{j}^{k}}>0\right)$ as soon as the representative consumer's preference for private consumption is sufficiently high $\left[\alpha_{c}>(1-2 v) \alpha_{g}\right]$. Indeed, if the capital taxation rate decreases in the other country, capital-importing country $i$ also usually decreases its own capital taxation rate in order to preserve its attractiveness for capital investment. Fiscal externalities can only be negative $\left(\frac{\partial t_{j}^{k}}{\partial t_{i}^{k}}<0\right)$ if the representative consumer's preference for public goods consumption is particularly high. In the latter case, a weaker foreign capital taxation rate reduces foreign direct investment and implies a loss of fiscal revenues for capital-importing country $i$. Therefore, the capital taxation rate in this country should increase in order to collect a sufficient level of fiscal resources to provide the high level of public goods and services desired by the representative consumer.

Equations (31) and (32) further imply: 


$$
\begin{aligned}
& \frac{\partial}{\partial\left(\frac{K_{j, j}}{K_{i, i}}\right)}\left(\frac{\partial t_{j}^{k}}{\partial t_{i}^{k}}\right)=-\frac{2 v^{3}(1-v)(1-\rho)^{2} \rho^{2} \alpha_{g}\left(2 \alpha_{c}-v \alpha_{c}+v \alpha_{g}\right)^{2}\left(\alpha_{c}-\alpha_{g}+2 v \alpha_{g}\right) K_{i, i}{ }^{2}}{\lambda_{i, j}^{(2) 3}} * \\
& \left\{\rho\left[v\left(3 \alpha_{c}-2 v \alpha_{c}+\alpha_{g}\right) t_{i}^{k}+2 \alpha_{c}(1-v)^{2}\right]\left[\alpha_{c}(1+2 \rho-2 v \rho)-\alpha_{g}(1-2 v-2 \rho+2 \rho v)\right] K_{j, j}\right. \\
& +2(1-v) \alpha_{g}(1-\rho) v\left(1-t_{i}^{k}\right)\left[\alpha_{c}(1+2 \rho-2 v \rho)-\alpha_{g}(1-2 v-2 \rho+2 \rho v)\right] K_{i, i} \\
& \left.-2(1-v) \alpha_{g}(1-\rho)\left(2 \alpha_{c}-v \alpha_{c}+v \alpha_{g}\right) \rho K_{i, i}\right\} \\
& \frac{\partial}{\partial\left(\frac{K_{i, i}}{K_{j, j}}\right)}\left(\frac{\partial t_{i}^{k}}{\partial t_{j}^{k}}\right)=-\frac{2 v^{2}(1-v)(1-\rho)^{2} \rho^{2} \alpha_{g}\left(2 \alpha_{c}-v \alpha_{c}+v \alpha_{g}\right)^{2}\left(\alpha_{c}-\alpha_{g}+2 v \alpha_{g}\right) K_{j, j}{ }^{2}}{\lambda_{i, j}^{(4) 3}} * \\
& \left\{2(1-v) \alpha_{g}(1-\rho) v\left(1-t_{j}^{k}\right)\left[\alpha_{c}(1+2 \rho-2 v \rho)-\alpha_{g}(1-2 v-2 \rho+2 \rho v)\right] K_{i, i}\right. \\
& -\left(3 \alpha_{c}-2 v \alpha_{c}+\alpha_{g}\right) \rho v\left(1-t_{j}^{k}\right)\left[\alpha_{c}(1+2 \rho-2 v \rho)-\alpha_{g}(1-2 v-2 \rho+2 \rho v)\right] K_{j, j} \\
& \left.+\rho^{2}\left(3 \alpha_{c}-2 v \alpha_{c}+\alpha_{g}\right)\left(2 \alpha_{c}-v \alpha_{c}+v \alpha_{g}\right) K_{j, j}\right\}
\end{aligned}
$$

According to the basic calibration of our model's parameters, ${ }^{7}$ the previous derivatives are usually negative, and big importing or exporting countries are usually less affected by variations in foreign taxation rates. Therefore, our analytical model further contributes by show that fiscal externalities seem higher and are a stronger question of interest for small countries, whereas big countries appear to be more insular and are relatively immune to variations in foreign interest rates.

\section{Conclusion}

Our model provides accurate theoretical results regarding optimal taxation rates and fiscal externalities in an open economy, for example in the framework of a monetary union. Our model shows that for capital-importing as well as capital-exporting countries, capital taxation rates should increase with country size, i.e., with the capital invested in the national country in comparison with that invested abroad. Indeed, large countries could bear the burden of higher capital taxation rates, and the risk of a race to the bottom related to near-zero taxation rates would only concern the smallest countries. In parallel, the fiscal weight could be very high and strongly rely on the labor

\footnotetext{
${ }^{7}$ If $\alpha_{c}>\alpha_{g}(1-2 v), \alpha_{c}(1+2 \rho-2 v \rho)-\alpha_{g}(1-2 v-2 \rho+2 \rho v)>4 \alpha \rho(1-v)^{2}>0$
} 
production factor for the smallest countries. Furthermore, for both capitalimporting and capital-exporting countries, the optimal capital taxation rate also increases with the representative consumer's relative preference for private versus public consumption because a higher rate provides a higher return for the consumer's sparing and because a weaker capital stock increases the capital production factor's productivity.

Therefore, capital taxation should mainly be used by the largest capital exporting countries whose representative consumers give a higher value to private consumption. In these conditions, capital taxation rates could remain non-negligible in big capital exporting countries: in Germany, in Italy, and mainly in France, where they are the highest in the EU. Even in a big capital importing country like Spain, they could also remain around 30\%. Therefore, the size of a country in terms of capital stock is well the main determinant of the level of capital taxation rates in the member countries of a monetary union. On the contrary, there is a risk that capital taxation rates could tend towards zero for the smallest countries. Therefore, our theoretical model has concrete policy implications, and it can explain why empirically, capital taxation rates are very weak today in particular in Luxembourg, but also in Lithuania or in Estonia.

We also find that in both capital-importing and capital-exporting countries, the optimal capital taxation rate increases with the share of capital in the production function because the larger capital fiscal base serves to increase the efficiency of taxing this production factor. Furthermore, the capital taxation rate should decrease with the average global rate of return on capital investment, thus increasing the required post-tax return on any potential interesting investment. We can also underline that the risk mentioned in the economic literature of a rising fiscal burden on the labor production factor in an open economy is not verified with our model. Indeed, taxing the capital production factor usually appears as optimal, whereas the conditions for mainly taxing the labor production factor are very restrictive. The share of capital should be very weak and the share of the labor factor in the production function should be excessively high in order to justify resorting to mainly taxing the labor production factor as a way to broaden the fiscal base.

Our model shows that the slope of the tax reaction function is positive, the national capital taxation rate varies in the same direction as the foreign capital taxation rate, if the representative consumer's preference for private goods 
consumption is sufficiently high. According to this slope, the government's aims become stabilizing the fiscal base and avoiding its potential leakage, whereas the level of public expenditure is endogenously allowed to vary. In contrast, the slope of the tax reaction function can only be negative if the representative consumer's relative preference for public goods consumption is particularly high and if reaching a desired exogenous high level of public services is the instrument used to maximize the representative consumer's utility. Finally, fiscal externalities seem higher for small countries, whereas the biggest countries seem relatively more insular and immune to variations of foreign interest rates.

Received 14 June 2018, Revised 27 September 2018, Accepted 2 November 2018

\section{References}

Altshuler, Rosanne, and Timothy .J. Goodspeed. "Follow the Leader? Evidence on European and US Tax Competition.” Public Finance Review vol.43, n4 (2015): 485-504.

Baldwin, Richard E., and Paul Krugman. "Agglomeration, Integration and Tax Harmonization." European Economic Review vol.48, n¹ (2004): 1-23.

Bond, Stephen, Lucy Chennells, Michael P. Devereux, Malcolm Gammie, and Edward Troup. Corporate Tax Harmonization in Europe: A Guide to the Debate. London: Institute for Fiscal Studies, 2000.

Bretscher, Lucas, and Frank Hettich. "Globalization, Capital Mobility and Tax Competition. Theory and Evidence for OECD Countries." European Journal of Political Economy vol.18, n4 (2002): 695-716.

Brueckner, Jan K. "Strategic Interaction among Governments: An Overview of Empirical Studies." International Regional Science Review vol.26, n² (2003): 
$175-188$.

Bucovetsky, Sam, and John D. Wilson. "Tax Competition with two Tax Instruments." Regional Science and Urban Economics vol.21, n³ (1991): 333350 .

Buettner, Thiess. "Local Business Taxation and Competition for Capital: The Choice of the Tax Rate." Regional Science and Urban Economics vol.31, n²/3 April (2001): 215-245.

Cassette, Aurélie, and Sonia Paty. "Tax Competition among Eastern and Western European Countries: With whom do Countries compete?" Economic Systems vol.32, $\mathrm{n}^{\circ} 4$ (2008): 307-325.

Chirinko, Robert, and Daniel Wilson. "Tax Competition among U.S. States: Racing to the Bottom or Riding on a Seesaw?" Journal of Public Economics vol.155 (2017): 147-163.

Davies, Ronald B., and Johannes Voget. Tax Competition in an Expanding European Union, GEE Papers 0033, Gabinete de Estratégia e Estudos, Ministério da Economia e da Inovação, Lisbon, Portugal. (2010)

De Mooij, Ruud A., and Sjef Ederveen. "Taxation and Foreign Direct investment: A Synthesis of Empirical Research." International Tax and Public Finance vol.10, n6, November (2003) : 673-693.

De Mooij, Ruud A., and Hendrik Vrijburg. "Tax Rates as Strategic Substitutes." Tinbergen Institute Discussion Papers $n^{\circ} 12-104 /$ VI (2012).

Devereux, Michael P. "The Impact of Taxation on the Location of Capital, Firms and Profit: A Survey of Empirical Evidence." Working Paper $n^{\circ} 07 / 02$, Oxford University Centre for Business Taxation (2007).

Devereux, Michael P., Rachel Griffith, and Alexander Klemm. "Corporate 
Income Tax Reforms and International Tax Competition." Economic Policy vol.17, n³5(2002): 451-495.

Devereux, Michael P., Ben Lockwood, and Michela Redoano. "Do Countries compete over Corporate Tax Rates?" Journal of Public Economics, vol.92, n ${ }^{\circ} 5$ 6 (2008): 1210-1235.

Devereux, Michael P., and Peter B. Sorensen. "The Corporate Income Tax: International Trends and Options for Fundamental Reform." European Economy, European Commission Economic Papers n²64, December (2006)

Dhillon, Amrita, Myrna Wooders, and Benjamin Zissimos. "Tax Competition reconsidered." Journal of Public Economic Theory, vol.9, n³(2007): 391-423.

Eggert, Wolfgang, and Andreas Haufler. "Company Tax Coordination cum Tax Rate Competition in the European Union." FinanzArchiv: Public Finance Analysis vol.62, $\mathrm{n}^{\circ} 4$ (2006): 579-601.

European Commission "Taxation Trends in the European Union. Data for the EU Member States, Iceland and Norway”, Luxembourg: Publications Office of the European Union (2018).

Garretson, Harry, and Jolanda Peeters. "Capital Mobility, Agglomeration and Corporate Tax Rates: Is the Race to the Bottom for real?" De Nederlandsche Bank Working Paper $\mathrm{n}^{\circ} 113$, September (2006).

Gorter, Joeri, and Ruud de Mooij. Capital Income Taxation in Europe: Trends and Trade-offs. The Hague: Central Planbureau, 2001.

Haufler, Andreas. "Prospects for Co-ordination of Corporate Taxation and the Taxation of Interest Income in the EU.” Fiscal Studies vol.20, n², June (1999): 133-153.

Haufler, Andreas, and Christoph Lulfesmann. "Reforming an Asymmetric 
Union: On the Virtues of Dual Tier Capital Taxation." Journal of Public Economics 125 (2015): 116-127.

Heinemann, Friedrich, Michael Overesch, and Johannes Rincke. "Rate Cutting Tax Reforms and Corporate Tax Competition in Europe." Center for European Economic Research (ZEW) Discussion Paper, n08-028. (2008).

Hines, James R. "Lessons from Behavioral Responses to International Taxation." National Tax Journal vol.52, n², June(1999): 305-22.

Hines, James R. "Corporate Taxation and International Competition." In Taxing Corporate Income in the $21^{\text {st }}$ Century, edited by Alan J. Auerbach, James R. Hines, and Joel Slemrod, , 268-295. Cambridge UK: Cambridge University Press, 2007

Keen, Michael, and Kai A. Konrad. "The Theory of International Tax Competition and Coordination." In Handbook of Public Economics, edited by Alan J. Auerbach, Raj Chetty, Martin Feldstein and Emmanuel Saez, volume 5,257-328,Amsterdam \& Oxford: Elsevier2013.

Keen, Michael, and Maurice Marchand. "Fiscal Competition and the Pattern of Public Spending." Journal of Public Economics vol.66, n²1, October (1997): 33-53.

Kind, Hans J., Karen H. M. Knarvik, and Guttorm Schjelderup. "Competing for Capital in a 'Lumpy' World." Journal of Public Economics, vol.78 (2000): 253-274.

Mendoza, Enrique G. "The International Macroeconomics of Taxation and the Case against European Tax Harmonization." NBER Working Paper n`8217, April (2001).

Oates, Wallace E. "Fiscal Competition and European Union: Contrasting Perspectives." Regional Science and Urban Economics vol.31, n²-3, 
April(2001): 133-145.

Parchet, Raphaël “Are Local Tax Rates Strategic Complements or Substitutes?” Universita de la Svizzera Italiana, Faculty of Economics, Working Paper 2015/07 (2013).

Parry, Ian W. H. "How Large are the Welfare Losses from Tax Competition?" Journal of Urban Economics vol.54(2003): 39-60.

Razin, Assaf, and Efraim Sadka. "Efficient Investment Incentives in the Presence of Capital Flight." Journal of International Economics vol.31, n¹-2, August(1991): 171-181.

Redoano, Michela. "Fiscal Interactions among European countries. Does the EU matter?” CESifo working paper n¹952 (2007).

Sinn, Hans-Werner. "The Selection Principle and Market Failure in Systems Competition." Journal of Public Economics, vol.66, n² (1997): 247-274.

Slemrod, Joel. “Are Corporate Tax Rates, or Countries, converging?” Journal of Public Economics vol.88, n ${ }^{\circ}$, June(2004): 1169-1186.

Sorensen, Peter B. "The Case for International Tax Co-ordination reconsidered." Economic Policy, vol.15, n³1, October(2000) : 429-472.

Sorensen, Peter B. "Tax Coordination in the European Union: What are the Issues?" Swedish Economic Policy Review 8, Winter(2001): 143-195.

Sorensen, Peter B. "International Tax Competition: A New Framework for Analysis. In: Economic Policy Issues for the Next Decade, edited by Karl Aiginger, and Gernot Hutschenreiter, Springer, Boston (2003): 189-201.

Sorensen, Peter B. "Can Capital Income Taxes survive? And should they?" CES-ifo Working Paper $n^{\circ} 1793$ (2006). 
Wildasin, David E. "Nash Equilibria in Models of Fiscal Competition." Journal of Public Economics vol.35, n²(1988): 229-240.

Wildasin, David E. "Tax Coordination: The Importance of Institutions, Swedish Economic Policy Review vol.9 (2002): 171-194.

Wildasin, David E., and John D. Wilson. "Capital Tax Competition: Bane or Boon?." Journal of Public Economics, vol.88 (2004): 1065-1091.

Wilson, John D. "A Theory of Interregional Tax Competition." Journal of Urban Economics vol.19, n³, May(1986): 296-315.

Wilson, John D. "Tax Competition with Interregional Differences in Factor Endowments." Regional Science and Urban Economics vol.21, n³(1991): 423451.

Wilson, John D. “Theories of Tax Competition.” National Tax Journal vol.52, n², June(1999): 269-304.

Zodrow, George R. “Capital Mobility and Capital Tax Competition.” National Tax Journal vol.63, n4, December(2010): 865-902. 


\section{Appendix A: Condition for the maximization of the utility function}

Equations (2), (4) and (11) imply:

$$
\begin{aligned}
C_{i}= & {\left[\frac{\left(1-t_{i}^{l}\right)(1-v) \rho}{v\left(1-t_{i}^{k}\right)}-(1-\rho)\right] K_{i, i}+\frac{\left(1-t_{i}^{l}\right)(1-v) \rho}{v\left(1-t_{i}^{k}\right)} K_{j, i}-(1-\rho) K_{i, j} } \\
\frac{\partial C_{i}}{\partial t}= & -\left[\frac{\rho(1-v)}{v\left(1-t_{i}^{k}\right)} \frac{\partial t_{i}^{l}}{\partial t}+\frac{\rho\left(1-t_{i}^{l}\right)(1-v)}{v\left(1-t_{i}^{k}\right)^{2}} \frac{\partial t_{i}^{k}}{\partial t}+\frac{(1-\rho)}{t}\left(\frac{\partial K_{i, i}}{\partial t} \frac{t}{K_{i, i}}\right)-\frac{\rho(1-v)\left(1-t_{i}^{l}\right)}{v\left(1-t_{i}^{k}\right) t}\left(\frac{\partial K_{i, i}}{\partial t} \frac{t}{K_{i, i}}\right)\right] K_{i, i} \\
& -\frac{(1-\rho)}{t}\left(\frac{\partial K_{j, j}}{\partial t} \frac{t}{K_{j, j}}\right) K_{i, j}-\frac{\rho(1-v)}{v}\left[\frac{1}{\left(1-t_{i}^{k}\right)} \frac{\partial t_{i}^{l}}{\partial t}+\frac{\left(1-t_{i}^{l}\right)}{\left(1-t_{i}^{k}\right)^{l}} \frac{\partial t_{i}^{k}}{\partial t}-\frac{\left(1-t_{i}^{l}\right)}{\left(1-t_{i}^{k}\right) t}\left(\frac{\partial K_{i, i}}{\partial t} \frac{t}{K_{i, i}}\right)\right] K_{j, i}<0
\end{aligned}
$$

Accordingly, a higher taxation rate reduces private consumption. Indeed, the smaller capital stock reduces labor productivity, wages, and private consumption. The higher tax also reduces the net-of-tax return on capital and interest income.

Equations (18), (4) and (11) imply:

$$
\begin{aligned}
G_{i} & =\rho \frac{\left(v t_{i}^{k}+t_{i}^{l}-v t_{i}^{l}\right)}{v\left(1-t_{i}^{k}\right)} K_{i, i}+\rho \frac{\left(v t_{i}^{k}+t_{i}^{l}-v t_{i}^{l}\right)}{v\left(1-t_{i}^{k}\right)} K_{j, i}+\rho x_{i} K_{i, j} \\
\frac{\partial G_{i}}{\partial t}= & \rho\left[\frac{(1-v)}{v\left(1-t_{i}^{k}\right)} \frac{\partial t_{i}^{l}}{\partial t}+\frac{\left(v+t_{i}^{l}-v t_{i}^{l}\right)}{v\left(1-t_{i}^{k}\right)^{2}} \frac{\partial t_{i}^{k}}{\partial t}+\frac{\left(v t_{i}^{k}+t_{i}^{l}-v t_{i}^{l}\right)}{v t\left(1-t_{i}^{k}\right)}\left(\frac{\partial K_{i, i}}{\partial t} \frac{t}{K_{i, i}}\right)\right] K_{i, i} \\
& +\rho\left[\frac{(1-v)}{v\left(1-t_{i}^{k}\right)} \frac{\partial t_{i}^{l}}{\partial t}+\frac{\left(v+t_{i}^{l}-v t_{i}^{l}\right)}{v\left(1-t_{i}^{k}\right)^{2}} \frac{\partial t_{i}^{k}}{\partial t}+\frac{\left(v t_{i}^{k}+t_{i}^{l}-v t_{i}^{l}\right)}{v t\left(1-t_{i}^{k}\right)}\left(\frac{\partial K_{i, i}}{\partial t} \frac{t}{K_{i, i}}\right)\right] K_{j, i} \\
& +\rho\left[\frac{\partial x_{i}}{\partial t}+\frac{x_{i}}{t}\left(\frac{\partial K_{j, j}}{\partial t} \frac{t}{K_{j, j}}\right)\right] K_{i, j}>0
\end{aligned}
$$

More precisely, the effect of a higher tax on public consumption depends on where the location on the Laffer curve. Below a given level, a higher tax rate raises revenues over the existing tax base. Nevertheless, beyond a given level, a higher tax rate reduces the domestic capital stock and causes an erosion of the tax base, especially if the tax rate is high. In order for the 
derivative to be positive, we must be on the upward-sloping part of the Laffer curve.

Condition (6) for the maximization of the utility function then implies:

$$
\begin{aligned}
& \frac{(1-v) \rho}{v\left(1-t_{i}^{k}\right)}\left[\frac{\alpha_{c}}{\alpha_{g}} x_{i} \frac{\partial t_{i}^{l}}{\partial t}-\left(1-t_{i}^{l}\right) \frac{\partial x_{i}}{\partial t}\right]\left(K_{i, i}+K_{j, i}\right) K_{i, j} \\
& +(1-\rho)\left[\frac{(1-v)}{v\left(1-t_{i}^{k}\right)} \frac{\partial t_{i}^{l}}{\partial t}\left(K_{i, i}+K_{j, i}\right)+\frac{\left(v+t_{i}^{l}-v t_{i}^{l}\right)}{v\left(1-t_{i}^{k}\right)^{2}} \frac{\partial t_{i}^{k}}{\partial t}\left(K_{i, i}+K_{j, i}\right)+\frac{\partial x_{i}}{\partial t} K_{i, j}\right]\left(K_{i, i}+K_{i, j}\right) \\
& +\rho \frac{\alpha_{c}}{\alpha_{g}} \frac{(1-v)\left(1-t_{i}^{l}\right)}{v\left(1-t_{i}^{k}\right)^{2}} \frac{\partial t_{i}^{k}}{\partial t}\left[x_{i} K_{i, j}+\frac{\left(v t_{i}^{k}+t_{i}^{l}-v t_{i}^{l}\right)}{v\left(1-t_{i}^{k}\right)}\left(K_{i, i}+K_{j, i}\right)\right]\left(K_{i, i}+K_{j, i}\right) \\
& +\frac{(1-v) \rho}{v^{2}\left(1-t_{i}^{k}\right)^{2}}\left[\frac{\alpha_{c}}{\alpha_{g}}\left(v t_{i}^{k}+t_{i}^{l}-v t_{i}^{l}\right) \frac{\partial t_{i}^{l}}{\partial t}-(1-v)\left(1-t_{i}^{l}\right) \frac{\partial t_{i}^{l}}{\partial t}-\frac{\left(v+t_{i}^{l}-v t_{i}^{l}\right)\left(1-t_{i}^{l}\right) \partial t_{i}^{k}}{\partial t}\right]\left(K_{i, i}+K_{j, i}\right)^{2} \\
& +\frac{\alpha_{c}}{\alpha_{g}}\left[(1-\rho)\left(\frac{\partial K_{i, i}}{\partial t} \frac{t}{K_{i, i}}\right) K_{i, i}+(1-\rho)\left(\frac{\partial K_{j, j}}{\partial t} \frac{t}{K_{j, j}}\right) K_{i, j}\right. \\
& \left.-\frac{(1-v) \rho\left(1-t_{i}^{l}\right)}{v\left(1-t_{i}^{k}\right)}\left(\frac{\partial K_{i, i}}{\partial t} \frac{t}{K_{i, i}}\right)\left(K_{i, i}+K_{j, i}\right)\right]\left[\frac{x_{i}}{t} K_{i, j}+\frac{\left(v t_{i}^{k}+t_{i}^{l}-v t_{i}^{l}\right)}{v t\left(1-t_{i}^{k}\right)}\left(K_{i, i}+K_{j, i}\right)\right] \\
& +\left[(1-\rho) K_{i, i}+(1-\rho) K_{i, j}-\frac{(1-v) \rho\left(1-t_{i}^{l}\right)}{v\left(1-t_{i}^{k}\right)}\left(K_{i, i}+K_{j, i}\right)\right] \\
& {\left[\frac{x_{i}}{t}\left(\frac{\partial K_{j, j}}{\partial t} \frac{t}{K_{j, j}}\right) K_{i, j}+\frac{\left(v t_{i}^{k}+t_{i}^{l}-v t_{i}^{l}\right)}{v t\left(1-t_{i}^{k}\right)}\left(\frac{\partial K_{i, i}}{\partial t} \frac{t}{K_{i, i}}\right)\left(K_{i, i}+K_{j, i}\right)\right]=0}
\end{aligned}
$$

\section{Appendix B: Optimal Taxation Rates}

We suppose that country $i$ is capital-importing whereas country $j$ is capitalexporting $\left(K_{i, j}=0 ; K_{j, i}>0\right)$.

We use the fact that $\frac{\partial \mathrm{K}_{i, i}}{\partial t_{i}^{k}} \frac{t}{i, i}_{K_{i, i}^{k}}=-\frac{t_{i}^{k}}{(1-v)\left(1-t_{i}^{k}\right)}(14) ; \frac{\partial \mathrm{K}_{j, j}}{\partial t_{i}^{k}} \frac{t_{i}^{k}}{\mathrm{~K}_{j, j}}=0(15)$;

$$
\frac{\partial K_{i, i}}{\partial t_{i}^{l}}=\frac{\partial K_{j, j}}{\partial t_{i}^{l}}=\frac{\partial K_{i, i}}{\partial t_{j}^{l}}=\frac{\partial K_{j, j}}{\partial t_{j}^{l}}=\frac{\partial x_{j}}{\partial t_{j}^{l}}=\frac{\partial t_{i}^{l}}{\partial t_{i}^{k}}=\frac{\partial t_{j}^{l}}{\partial t_{j}^{k}}=\frac{\partial t_{i}^{k}}{\partial t_{i}^{l}}=\frac{\partial t_{i}^{k}}{\partial t_{j}^{l}}=\frac{\partial t_{j}^{k}}{\partial t_{i}^{l}}=\frac{\partial t_{j}^{k}}{\partial t_{j}^{l}}=\frac{\partial t_{i}^{k}}{\partial t_{j}^{k}}=0 .
$$

\section{Regarding capital importing country $i$ :}


Equation (A5) implies that the optimal labor taxation rate $\left(t_{i}^{l}\right)$ is:

$$
\left(1-t_{i}^{l}\right)=\frac{\alpha_{c}\left(1-v+v t_{i}^{k}\right)}{\left(\alpha_{c}+\alpha_{g}\right)(1-v)}+\frac{\alpha_{g}(1-\rho) v\left(1-t_{i}^{k}\right)}{\left(\alpha_{c}+\alpha_{g}\right) \rho(1-v)} \frac{K_{i, i}}{\left(K_{i, i}+K_{j, i}\right)}
$$

Equation (A5) further implies that the optimal capital taxation rate $\left(t_{i}^{k}\right)$ verifies:

$$
\begin{aligned}
& \left(-v \alpha_{c} t_{i}^{k}-v \alpha_{g} t_{i}^{k}-\alpha_{c}+v \alpha_{c}\right) v(1-\rho)\left(1-t_{i}^{k}\right) K_{i, i} \\
& +v\left(1-t_{i}^{k}\right)(1-v)(1-\rho)\left(1-t_{i}^{l}\right)\left(\alpha_{c}+\alpha_{g} v\right) K_{i, i} \\
& +\rho\left(2 v \alpha_{c} t_{i}^{k}-v \alpha_{c} t_{i}^{k} v+v \alpha_{g} t_{i}^{k}+2 \alpha_{c}-3 v \alpha_{c}+v v \alpha_{c}\right)(1-v)\left(1-t_{i}^{l}\right)\left(K_{i, i}+K_{j, i}\right) \\
& -\rho(1-v)(1-v)\left(1-t_{i}^{l}\right)^{2}\left(2 \alpha_{c}-v \alpha_{c}+v \alpha_{g}\right)\left(K_{i, i}+K_{j, i}\right)=0
\end{aligned}
$$

Therefore, putting the expression of $\left(1-t_{j}^{l}\right)$ from (B1) in Equation (B2) produces:

$$
\begin{aligned}
& (1-\rho)^{2} v^{2}\left(1-t_{i}^{k}\right)^{2}\left(\alpha_{c}-\alpha_{g}+2 v \alpha_{g}\right) K_{i, i}{ }^{2} \\
& +\rho(1-\rho) v\left(1-t_{i}^{k}\right) K_{i, i}\left(K_{i, i}+K_{j, i}\right)\left[-2\left(2 \alpha_{c}-v \alpha_{c}+v \alpha_{g}\right)\left(1-v+v t_{i}^{k}\right)+\left(\alpha_{c}+\alpha_{g}\right)(1-v)\right] \\
& +2 \rho^{2} \alpha_{c}(1-v)^{2}\left(1-v+v t_{i}^{k}\right)\left(K_{i, i}+K_{j, i}\right)^{2} \\
& +\rho^{2} t_{i}^{k} v\left(3 \alpha_{c}-2 \alpha_{c} v+\alpha_{g}\right)\left(1-v+v t_{i}^{k}\right)\left(K_{i, i}+K_{j, i}\right)^{2}=0
\end{aligned}
$$

Equation (B3) can then be reduced to the following expression:

$$
\begin{aligned}
& {\left[\rho\left(1-v+v t_{i}^{k}\right)\left(K_{i, i}+K_{j, i}\right)-(1-\rho) v\left(1-t_{i}^{k}\right) K_{i, i}\right] *} \\
& \left\{\left[2 \alpha_{c}(1-v)\left(1-v+v t_{i}^{k}\right)+\left(\alpha_{c}+\alpha_{g}\right) v v_{i}^{k}\right] \rho\left(K_{i, i}+K_{j, i}\right)-\left(\alpha_{c}-\alpha_{g}+2 v \alpha_{g}\right)(1-\rho) v\left(1-t_{i}^{k}\right) K_{i, i}\right\} \\
& =0
\end{aligned}
$$

Therefore, this Equation (B4) implies either: 


$$
\begin{gathered}
\rho\left(K_{i, i}+K_{j, i}\right)-v\left(1-t_{i}^{k}\right)\left(K_{i, i}+\rho K_{j, i}\right)=0 \\
\text { or } \\
{\left[\left(3 \alpha_{c}-2 v \alpha_{c}+\alpha_{g}\right) \rho\left(K_{i, i}+K_{j, i}\right)+\left(\alpha_{c}-\alpha_{g}+2 v \alpha_{g}\right)(1-\rho) K_{i, i}\right] *} \\
v\left(1-t_{i}^{k}\right)-\left(2 \alpha_{c}-v \alpha_{c}+v \alpha_{g}\right) \rho\left(K_{i, i}+K_{j, i}\right)=0
\end{gathered}
$$

\section{Regarding capital-exporting country $j$ :}

Equation (A5) implies that the optimal labor taxation rate $\left(t_{j}^{l}\right)$ is:

$$
\left(1-t_{j}^{l}\right)=\frac{\alpha_{c}\left(1-v+v t_{j}^{k}-v x_{j}+v x_{j} t_{j}^{k}\right)}{\left(\alpha_{c}+\alpha_{g}\right)(1-v)}+\frac{\left(\alpha_{g}-\rho \alpha_{g}+\rho x_{j} \alpha_{c}\right) v\left(1-t_{j}^{k}\right)}{\left(\alpha_{c}+\alpha_{g}\right) \rho(1-v)} \frac{\left(K_{j, j}+K_{j, i}\right)}{K_{j, j}}
$$

Besides, Equation (A5) implies that the optimal capital taxation rate $\left(t_{j}^{k}\right)$ verifies:

$$
\begin{aligned}
& \alpha_{g} v^{2}\left(1-t_{j}^{k}\right)^{3}(1-v)(1-\rho) \frac{\partial x_{j}}{\partial t_{j}^{k}} K_{j, i}\left(K_{j, j}+K_{j, i}\right)-\alpha_{c} v^{2}(1-\rho)\left(1-t_{j}^{k}\right)^{2} x_{j} K_{j, i} K_{j, j} \\
& -\alpha_{g} v^{2}\left(1-t_{j}^{k}\right) t_{j}^{k}(1-\rho) K_{j, j} K_{j, i}-\left(\alpha_{c}-v \alpha_{c}+\alpha_{c} v t_{j}^{k}+\alpha_{g} v t_{j}^{k}\right) v(1-\rho)\left(1-t_{j}^{k}\right) K_{j, j}{ }^{2} \\
& -\rho \alpha_{g} v\left(1-t_{j}^{k}\right)^{2}(1-v)^{2}\left(1-t_{j}^{l}\right) \frac{\partial x_{j}}{\partial t_{j}^{k}} K_{j, j} K_{j, i}+\rho \alpha_{c} v\left(1-t_{j}^{k}\right)(1-v)(2-v)\left(1-t_{j}^{l}\right) x_{j} K_{j, i} K_{j, j} \\
& +\alpha_{g} v^{2}\left(1-t_{j}^{k}\right)(1-v)(1-\rho)\left(1-t_{j}^{l}\right) K_{j, j} K_{j, i}-\alpha_{g} v\left(1-t_{j}^{k}\right)(1-v)^{2}(1-\rho)\left(1-t_{j}^{l}\right) K_{j, j}{ }^{2} \\
& +\left(\alpha_{c}+\alpha_{g}\right) v(1-\rho)\left(1-t_{j}^{k}\right)\left(1-t_{j}^{l}\right)(1-v) K_{j, j}{ }^{2}+\rho \alpha_{c}(1-v)^{2}\left(2-v+v t_{j}^{k}\right)\left(1-t_{j}^{l}\right) K_{j, j}{ }^{2} \\
& +\rho\left(\alpha_{c}+\alpha_{g}\right)(1-v)\left(1-t_{j}^{l}\right) v t_{j}^{k} K_{j, j}{ }^{2}-\rho(1-v)^{2}\left(2 \alpha_{c}-v \alpha_{c}+v \alpha_{g}\right)\left(1-t_{j}^{l}\right)^{2} K_{j, j}{ }^{2} \\
& =0
\end{aligned}
$$

Therefore, putting the expression of (1- $\left.t_{j}^{l}\right)$ from (B6) in Equation (B7) yields: 


$$
\begin{aligned}
& 2\left(\alpha_{c}-\alpha_{g}\right)(1-v)(1-\rho) v\left(1-t_{j}^{k}\right)\left(K_{j, j}+K_{j, i}\right)\left[v\left(1-t_{j}^{k}\right)\left(K_{j, j}-x_{j} K_{j, i}\right)-K_{j, j}\right] \\
& -2(1-v) v^{2}\left(1-t_{j}^{k}\right)^{2} \alpha_{g} \frac{(1-\rho)^{2}}{\rho}\left(K_{j, i}+K_{j, j}\right)^{2}+\left(\alpha_{c}+\alpha_{g}\right) v^{2}\left(1-t_{j}^{k}\right)^{2} \frac{(1-\rho)^{2}}{\rho}\left(K_{j, j}+K_{j, i}\right) K_{j, j} \\
& +\left(\alpha_{c}+\alpha_{g}\right)(1-\rho) v^{2}\left(1-t_{j}^{k}\right)\left[\left(1-t_{j}^{k}\right)-1\right] K_{j, j}\left(K_{j, j}+K_{j, i}\right) \\
& +\left(\alpha_{c}+\alpha_{g}\right) v^{2}\left(1-t_{j}^{k}\right)^{3}(1-v)(1-\rho) \frac{\partial x_{j}}{\partial t_{j}^{k}} K_{j, i}\left(K_{j, j}+K_{j, i}\right) \\
& +\left(\alpha_{c}+\alpha_{g}\right) v\left(1-t_{j}^{k}\right)(1-\rho) K_{j, j}\left[v\left(1-t_{j}^{k}\right)\left(K_{j, j}-x_{j} K_{j, i}\right)-K_{j, j}\right] \\
& +\rho\left(\alpha_{c}+\alpha_{g}\right) v\left(1-t_{j}^{k}\right)^{2}(1-v) \frac{\partial x_{j}}{\partial t_{j}^{k}} K_{j, i}\left[v\left(1-t_{j}^{k}\right)\left(K_{j, j}-x_{j} K_{j, i}\right)-K_{j, j}\right] \\
& -\rho v t_{j}^{k}\left(\alpha_{c}+\alpha_{g}\right) K_{j, j}\left[v\left(1-t_{j}^{k}\right)\left(K_{j, j}-x_{j} K_{j, i}\right)-K_{j, j}\right] \\
& +2 \rho \alpha_{c}(1-v)\left[v\left(1-t_{j}^{k}\right)\left(K_{j, j}-x_{j} K_{j, i}\right)-K_{j, j}\right]^{2} \\
& =0
\end{aligned}
$$

Equation (B8) can be reduced to the following expression:

$$
\begin{aligned}
& {\left[\left(v-v t_{j}^{k}-\rho\right) K_{j, j}+\left(1-\rho-\rho x_{j}\right) v\left(1-t_{j}^{k}\right) K_{j, i}\right] *} \\
& \left\{-2 \rho\left(\alpha_{c}+\alpha_{g}\right)(1-v)\left[\left(1-v+v t_{j}^{k}\right) K_{j, j}+v x_{j}\left(1-t_{j}^{k}\right) K_{j, i}\right]\right. \\
& -2 \alpha_{g}(1-v)\left[\left(v-v t_{j}^{k}-\rho\right) K_{j, j}+\left(1-\rho-\rho x_{j}\right) v\left(1-t_{j}^{k}\right) K_{j, i}\right] \\
& \left.+\rho\left(\alpha_{c}+\alpha_{g}\right) v\left(1-t_{j}^{k}\right)^{2}(1-v) \frac{\partial x_{j}}{\partial t_{j}^{k}} K_{j, i}+\left(\alpha_{c}+\alpha_{g}\right) v K_{j, j}\left(1-t_{j}^{k}-\rho\right)\right\} \\
& =0
\end{aligned}
$$

This Equation (B9) implies either:

$$
\begin{gathered}
\left(v-v t_{j}^{k}-\rho\right) K_{j, j}+\left(1-\rho-\rho x_{j}\right) v\left(1-t_{j}^{k}\right) K_{j, i}=0 \\
\quad \text { or } \\
-\rho\left(2 \alpha_{c}-v \alpha_{c}+v \alpha_{g}\right) K_{j, j}-v \alpha_{g}(1-2 v-2 \rho+2 \rho v)\left(1-t_{j}^{k}\right) K_{j, j} \\
+\rho\left(\alpha_{c}+\alpha_{g}\right) v\left(1-t_{j}^{k}\right)^{2}(1-v) \frac{\partial x_{j}}{\partial t_{j}^{k}} K_{j, i} \\
=0
\end{gathered}
$$

